九州大学学術情報リポジトリ

Kyushu University Institutional Repository

\title{
A revision of the subfamily Psyllinae from Japan. I (Hemiptera: Psyllidae)
}

Miyatake, Yorio

Entomological Laboratory, Department of Agriculture, Kyushu University

https://doi.org/10.5109/22707

出版情報: 九州大学大学院農学研究院紀要. 12 (4)，pp.323-357，1963-08. Kyushu University バージョン：

権利関係 : 
Journal of the Faculty of Agriculture, Kyushu University, Vol. 12, No. 4 August 30, 1963

A revision of the subfamily Psyllinae from Japan. I

(Hemiptera: Psyllidae)*

Yorio MIYATAKE

\section{INTRODUCTION}

The subfamily Psyllinae is the largest and the most numerously represented of the subfamilies in the world. As far as known, 17 or more genera and about 500 species belong to this subfamily, including famous "Pear-sucker" (Psylla pyrisuga Förster), "Apple-sucker" (Psylla mali (Schmidberger)), and many other species which are of economic importance.

Up to the present time 31 species of Psyllinae have been known from Japan proper. In addition to these, 17 species are newly described and 9 species are newly recorded in this paper.

The first recorded species of this subfamily from Japan is Psylla pyrisuga Förster which was recorded by Schwarz (1896). In 1899, Horváth described a new species, Psylla hexastigma basing upon the specimens from Amur and Japan (Hokkaido).

The most important study of the Japanese Psyllinae was done by Kuwayama in 1908. He put 4 known genera, Psylla, Calophya, Diaphorina, Homotoma and 4 new genera, Metapsylla, Epipsylla, Mesohomotoma, Macrohomotoma, comprising 13 known species and 30 new species as shown in the following pages, into this subfamily. This revision was made basing on the specimens brought from Japan proper and Formosa. Later, in 1911, Calophya was transferred to Pauropsyllinae and Homotoma, Mesohomotoma, Macrohomotoma to Carsidarinae by Crawford.

In 1915, T. Sasaki described a new species, Psylla malivorella which was causing heavy injuries to the apple trees in central Japan. Kuwayama, Jr. described the following new species one by one: Psylla amakusensis in 1939, $P$. horii in 1943, and $P$. japonica in 1955 . He

* Contribution Ser. 2, No. 172, Entomological Laboratory, Kyushu University. 
recorded Psylla ledi Flor from Hokkaido for the first time in 1961.

Shinji described many new species, apparently without seeing any specimens of many of the species involved, Psylla poligoni, P. tadeana, P. itadori, P. artemisifoliae in 1938 and P. fulvicola, P. polygonifoliae in 1942 all of which without any doubt should be referred to the genus Aphalara of the subfamily Aphalarinae as partly mentioned by $\mathrm{K}$. Sasaki (1954). In the check list of the known species of the subfamily with records of the host plants made by $\mathrm{K}$. Sasaki in 1954, he added some new habitats and new host plants basing upon his own observations in the field.

The materials treated in this paper were mainly from the collections of the Entomological Laboratory of Kyushu University, the Entomological Laboratory of Ehime University (including Sasaki's collection) and my private collection. Although the Amami-Oshima Islands belong to Japan, this area is omitted in this paper, since their psyllid fauna is not similar to that of Japan proper but entirely Oriental.

Before going further, I wish to express my cordial appreciation to Prof. K. Yasumatsu and Prof. Y. Hirashima of Kyushu University for their continuous guidance and encouragement in the course of the present work. My deep thanks are also due to Dr. Satoru Kuwayama for the gift of reprints of his papers and kind advices, Prof. C. Watanabe of Hokkaido University for giving me the chance to examine Kuwayama's type-specimens deposited in Hokkaido University, Prof. $T$. Ishihara of Ehime University who kindly placed the material of that institution at my disposal, and the following gentlemen for their useful advices and/or gifts of the materials: Dr. K. Baba, Mr. I. Hiura, Mr. T. Hidaka, Mr. Y. Hirose, Mr. S. Kimoto, Mr. H. Kamiya, Mr. T. Kawarabata, Dr. H. Kuroko, Mr. M. Miyatake, Prof. S. Miyamoto, Dr. K. Morimoto, Mr. Y. Maeta, Dr. Y. Murakami, Mr. F. Nakasuji, Mr. K. Ôshima, Mr. K. Sasaki, Mr. T. Saigusa, Prof. T. Shirôzu, Mr. M. Shiga, Mr. M. Sonda, Mr. M. Tonosaki, Mr. M. Takahashi and Mr. K. Yano. To Prof. L. D. Tuthill of the University of Hawaii and Prof. D. D. Jensen of the University of California, I am deeply grateful for their kind gifts of reprints of their papers and kind advices, and also to Dr. V. F. Eastop of the British Museum (Natural History) who has kindly enabled me to study the specimens of the psyllid collection under his care for comparison.

All the holotypes and some paratypes of new species are preserved in the collection of the Entomological Laboratory, Kyushu University.

The terminology employed in this paper is mainly adopted from D. L. Crawford, 1914, “A Monograph of the Jumping Plant-lice or Psyllidae of the New World." The scientific names of the host plants follow T. Makino, 1961, "Makino's New Illustrated Flora of Japan." 
The habitats and the host plants marked with asterisk are recorded for the first time in this paper.

\section{Subfamily Psyllinae Löw}

Psyllinae Löw, 1879, Verh. zool.-bot. Ges. Wien 28: 605, 607.

Psyllaria Puton, 1886, Cat. Hém. Faune Paléa.: 91.

Psyllidae Edwards, 1896, Hemip.-Homop. Br. Is.: 227, 233.

Type-genus: Psylla Geoffroy, 1762.

Head more or less deflexed, sometimes vertical. Vertex large and often quadrate. Genae produced into variously shaped lobes or cones beyond end of vertex, contiguous or divergent. Frons covered by genae, visible only as a very small sclerite bearing median ocellus (except for Psylla sasakii Y. Miyatake). Antennae typically ten-segmented, length variable, two basal segments without exception much broader than other segments, with two apical setae. Thorax usually well arched. Forewings variable from thick to transparent, rhomboidal to elongate-ovate, usually rounded at apex; pterostigma present or absent, media and cubitus always with a common petiole. Hindwings normally developed, usually more than half as long as forewings, with rudimental veins. Posterior tibiae often with a basal spur, with variable number of black spines apically. Proximal segment of posterior tarsi usually with a pair of black spines, sometimes absent. Meracanthus present, varies in shape and length, produced caudad or ventrad or ventro-caudad. Male proctiger simple, sometimes produced caudad or with a secondary lobe.

There occur two genera of this subfamily in Japan proper and each of them is distinguishable as shown in the following key.

\section{Key to the genera of Psyllinae of Japan proper}

1 (2). Antennae short, not longer than width of head; forewings thick and coriaceous, with veins strongly bisinuate; proximal segment of posterior tarsi without a pair of apical spines .................................Metapsylla

2 (1) Antennae long, at least longer than width of head; forewings not coriaceous, with veins slightly sinuate; proximal segment of posterior tarsi with a pair of apical spines Psyllit

\section{Genus Metapsylla Kuwayama}

Mctafsylla Kuwayama, 1908, Trans. Sapporo Nat. Hist. Soc. 2: 157.

Type-species: Metapsylla nigra Kuwayama, 1908 (original designation by Kuwayama in 1908).

Head small, narrower than thorax, subvertical. Vertex somewhat quadrate, rugose, usually longer than half as long as wide. Genal cones very small, strongly divergent, blunt apically, pubescent. Eyes rather small, hemispherical. Occiput visible in caudal aspect. Antennae very short and prominent, not longer than 
width of head, scape and pedicel broad and fully as long as flagellum, with two long apical setae of the same length. Frons not visible.

Thorax broad, stout, strongly arched, rugose, not pubescent. Pronotum large, subvertical, a little below plane of vertex. Forewings broad, rounded apically, thick and coriaceous, quite opaque, with maculations; pterostigma distinctly long, indistinctly closed basally, tapering well towards tip of wing; $\mathrm{C}+\mathrm{Sc}$ thickened; veins strongly bisinuate; media and cubitus with common petiole; marginal cells large. Hindwings long, almost reaching apex of forewings. Legs short but stout; anterior and middle femora strongly swollen, posterior tibiae without basal spur, with 5 or 6 apical spines; proximal segment of posterior tarsi without black, apical spines. Meracanthus short and very prominent, somewhat hemi. spherical in lateral aspect, produced ventro-caudad.

Male genital segments very small, as long as the rest of abdomen; proctiger longer than forceps, stout; forceps very short, with an anterior lobe produced mesad. Female genital segments short, sharp; dorsal valve attenuate in the apical third.

M. marginata Kuwayama, 1908 of Formosa (Koshun) should be referred to Euphalerus Schwarz, 1901, since its forewings are maculated but transparent, the pterostigma is not defined, $\mathrm{C}+\mathrm{Sc}$ is not distinctly thickened, genal cones are broad and somewhat quadrate, and the proximal segment of posterior tarsi has a pair of black, apical spines (type; $\&$ in the Entomological Institute of Hokkaido University was examined).

M. robinue Shinji, 1938, as noticed by Yu (1956), seems to belong to the different genus rather than Metapsylla (supposedly to Arytaina Förster), because of having the forewings rather hyaline and veins not strongly sinuate, lacking the distinct pterostigma, and having the proximal segment of the posterior tarsi with a pair of apical spines. It might be better to leave it, however, unless further and more detailed researches would be done.

\section{Metapsylla nigra Kuwayama}

(Fig. 1, A-D)

Metapsylla nigra Kuwayama, 1908, Trans. Sapporo Nat. Hist. Soc. 2: 157 (Kagoshima, Japan).

This species was described only basing upon the female. However, the male differs only in dimensions. Descriptions of both the male and the female genitalia are given below.

Male genital segments small, less than half as long as the rest of abdomen, pubescent; proctiger short and stout, about two times as long as forceps, somewhat wedge-shaped, broadened basally and narrowed apically, with anterior margin straight, apically with anus very small, more pubescent posteriorly than anteriorly; forceps very short and broad, strongly sclerotized, margins bisinuate as figured in lateral view, diagonally truncate at apex, anterior apical ridge strongly produced mesad as a secondary lobe, in caudal view arched, stout, with an apical portion touched, with the inner face beset with a patch of strong setae, in dorsal view touching at two points, anterior lobes and posterior angle, making a right-triangular space between them; aedeagus moderately long, continuously broad in both first and second segments, first segment not bent but straight and 
slightly shorter than second, second segment bent near midpoint; subgenital plate somewhat pentagonal, almost as high as proctiger, with anterior margin straight. Female genital segments very small, sharp, half as long as the rest of abdomen, normally pubescent, more dense in the apical half; dorsal valve somewhat right-angled triangular, tapering to blunt apex and more or less upturned, strongly attenuate in the apical third, shorter than ventral; inner valve much
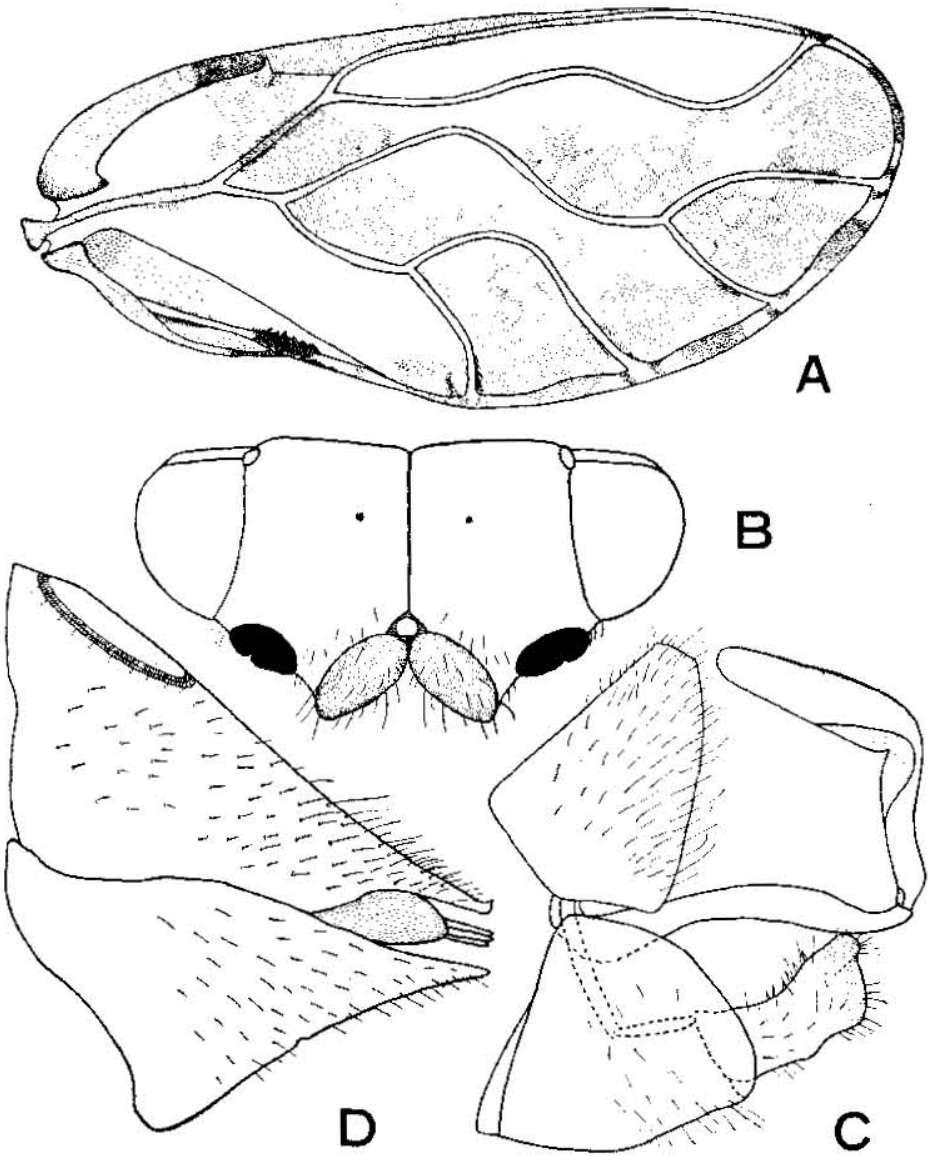

Fig. 1. Metapsylla nigra Kuwayama.

A. Forewing, ?. B. Head (antennae excluded), frontal aspect, s.

C. Male genitalia, lateraI aspect. D. Female genitalia, lateral aspect.

longer than dorsal and distinctly longer than ventral, blunt apically; ventral valve wider than dorsal at base, narrowed in the apical third and horizontal, subacute apically, with dorsal margin bisinuate.

Length of body $\$ 2.1-2.6 \mathrm{~mm}$, $92.7-3.0 \mathrm{~mm}$ (to tip of folded wings $3.0-3.1$ 
$\mathrm{mm}$, $3.1-3.3 \mathrm{~mm}$ ); length of forewing $\$ 2.5 \mathrm{~mm}, 2.6-2.8 \mathrm{~mm}$; length of antenna $50.3 \mathrm{~mm}$, $\$ 0.3-0.4 \mathrm{~mm}$.

Distribution: Japan (Kyushu, Shikoku).

Type-specimen examined: 1\%, 10. vii. 1903, Kagoshima (preserved in the Entomological Institute of Hokkaido University).

Specimens examined: 1 g, Matsuyama, Ehime Pref., Shikoku, 6. viii. 1951, M. Miyatake leg. 2554 \% 1954; Matsuyama city, Shikoku, K. Sasaki leg. 1\%, Dogo, Matsuyama, Shikoku, 23. viii. 195̄3, T. Yano leg. $2801 \div 21$. v. 1958 (on Qucrcus sp.); 1 ㅇ, 8. ix. 1958 ; 1 ? 1 , 2. iv. $1959 ; 1$, 29. v. 1959 on Myrica rubra; 4331 \%, 24. vi. $1959 ; 35 \%, 4$. vii. 1959; Hirao, Fukuoka city, Kyushu, Y. Miyatake leg. 23529 , Tomioka, Amakusa, Kyushu, 20-25. vi. 1931, Esaki \& Hori leg. $152 \%$, Beppu, Bungo, Kyushu, 1. i. 1937, T. Torigata leg.

Host plant: "Chishanoki"--Ehretia ovalifolia Hasskarl [Borraginaceae]; larva? and imago, Sasaki, $1954: 33$.

\section{Metapsylla uei Y. Miyatake, sp. nov.}

(Fig, 2, A-E)

¿ ' : General colour light to greenish brown with rather distinct dark brownish markings on dorsum of thorax and vertex near posterior margin; eyes dark brown; antennae slightly reddish brown apically; abdomen more or less reddish with a transverse black band along segments, especially on tergites; genital segments darker. Forewings rather thick and coriaceous, quite opaque, tes. taceous, with a broad band of dark brownish colour along margin from tip of Rs to tip of $\mathrm{Cu}_{2}$; veins usually light brown with brown spots on the sides regularly. marginal vein alternately brown and white, clavus white, A with a large black spot near midpoint.

Head small, distinctly narrower than thorax, subvertical, not deflexed below level of pronotum; vertex large, quadrate, a little longer than half as long as wide on median line, with small and shallow impressions located near center of each side, slightly rugose, not pubescent, with posterior margin nearly straight; genal cones small and very peculiar, half as long as vertex, separated at base, strongly divergent, lobate, subparallel with anterior margin of vertex, blunt apically, strongly pubescent, on same plane of vertex; occiput large, slightly visible in caudal view; eyes small, hemispherical; antennae quite short, nearly as long as vertex, with I and II stout, with flagellum very short and bead-like, with two apical setae as long as pedicel, relative lengths of the antennal segments as $8: 8: 4: 2: 1: 2: 1: 2: 2: 2$.

Thorax very broad, robust, strongly arched, much more rugose than vertex and coarsely punctate (especially on scutum), never pubescent; pronotum large, slightly wider than head, almost as long as vertex, with anterior margin rather straight and posterior margin slightly curved caudad, slightly below plane of vertex; praescutum small, produced laterally as a long arm; scutum well arched, even angular, concave medially, wider than long, about $18 \times 7$; scutellum large, trapezoidal, shorter than wide, about $2 \times 1$. Legs massive but short, pubescent; anterior and middle femora swollen and short; posterior tibia without a basal spur, with 1 outer and $\vec{\jmath}$ inner (two of these very small) apical spines; proximal 
segment of anterior tarsi short and reduced, much smaller than apical segment; meracanthus short, broadly rounded apically, somewhat wart-like (Fig. 2, E), Forewings broadly ovate and broadly rounded at apex, almost two times as long as wide; pterostigma distinct and long, almost reaching apex of wing, quite wide

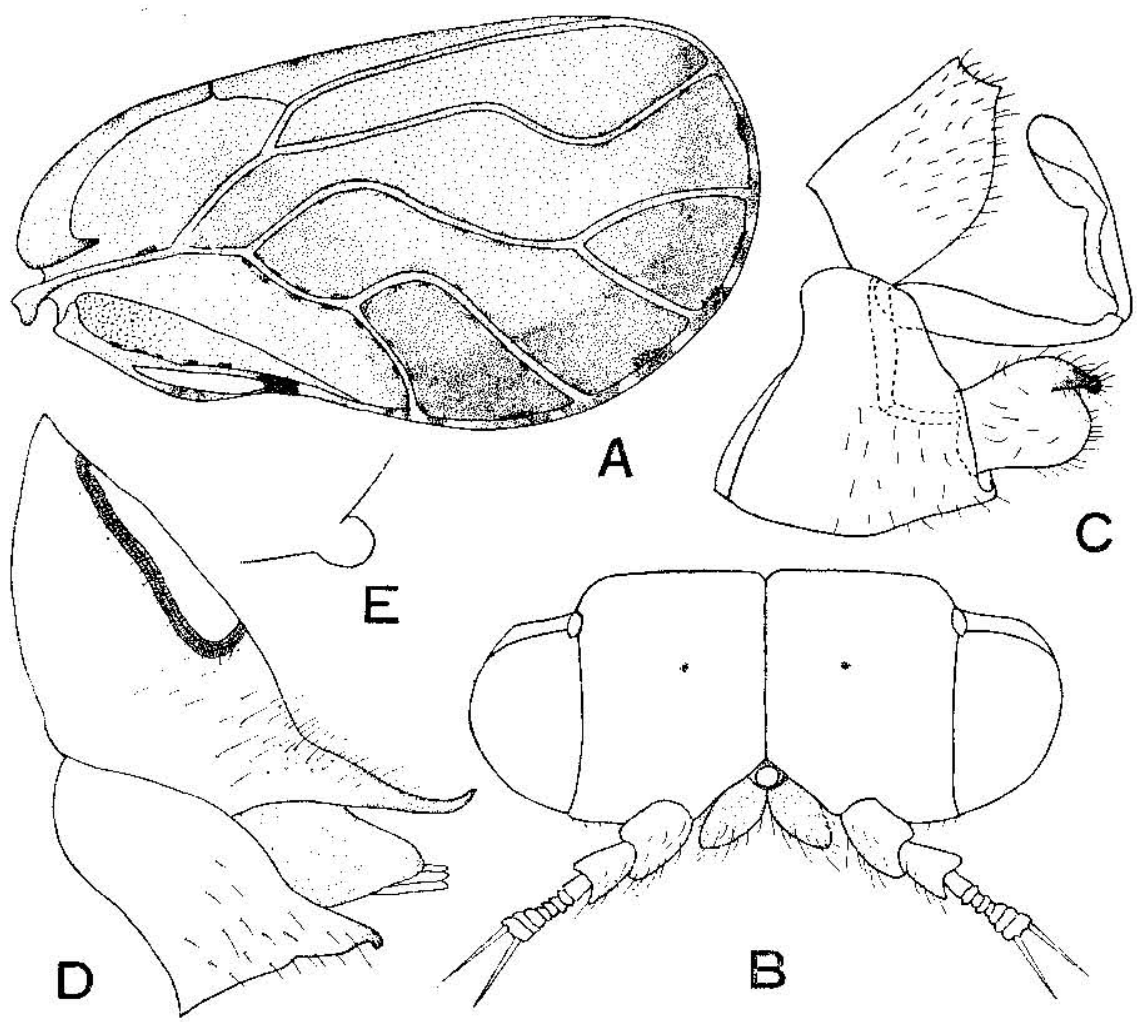

Fig. 2. Metapsylla tei Y. Miyatake, sp. nov.

A. Forewing, $\because$ B. Head, frontal aspect, $?$ C. Male genitalia, lateral aspect,

D. Female genitalia, Iateral aspect. E. Meracanthus, lateral aspect.

basally; veins coarse and strongly bisinuate as figured, especially Rs, M-stem and $\mathrm{Cu}_{1}$, with numerous microtrichiae on both sides; $\mathrm{C}+\mathrm{Sc}$ distinctly thickened, without conspicuous pubescence anteriorly; $\mathrm{R}$-stem and $\mathrm{M}+\mathrm{Cu}$ rather straight; relative lengths of the veins $\mathrm{R}, \mathrm{M}+\mathrm{Cu}, \mathrm{Cu}, \mathrm{Cu}_{1}, \mathrm{M}_{1+2}$, and $\mathrm{M}_{3+4}$ as $16: 7: 10: 16: 19$ : 15; first marginal (cubital) cell high, much larger than second (medial); second marginal cell subtriangular, small. Abdomen (excl. genital segments) stout, long, as long as width of head, scarcely pubescent, rugged.

Male genital segments very small; proctiger short but stout in lateral view, distinctly longer than forceps, broad basally, with anterior margin bare and smooth, with posterior margin produced slightly caudad and finely pubescent; forceps markedly short, peculiar as figured, with a long apical, hook-like lobe 
produced anteriorly and sclerotized, with posterior margin rather straight, with anterior margin curved anteriorly, with an apex broadly rounded, in caudal view stout, heavy, scarcely arched, with inner face densely pubescent; aedeagus very short, broad, relative lengths of first segment and second segment 1:0.9; subgenital plate usually covered with terminal segment of abdomen anteriorly, small, subtriangular in lateral view, with anterior margin straight, with dorsal and ventral margins sinuate, pubescent.

Female genital segments rather large, almost as long as the rest of abdomen, slender, pubescent; dorsal valve much longer than ventral, descending, apical third elongate and strongly attenuate, with apex sharply upturned, with anus very large and almost as long as the rest of dorsal valve in larger diameter in dorsal view; inner valve slightly shorter than dorsal, but distinctly longer than ventral; ventral valve small in lateral view, with apical portion slender to sharp tip in the apical third.

Length of body $1.9-2.0 \mathrm{~mm}, 2.1-2.2 \mathrm{~mm}$ (to tip of folded wings $2.6-2.7$ $\mathrm{mm}, ? 2.9-3.0 \mathrm{~mm}$ ); length of forewing $32.2-2.3 \mathrm{~mm}, \quad 2.2-2.3 \mathrm{~mm}$; length of antenna $0.2-0.3 \mathrm{~mm}, \quad 0.2-0.3 \mathrm{~mm}$.

Distribution: Japan (Kyushu, Shikoku).

Holotype (6): Tatsutayama, Kumamoto city, Kyushu, 29-30. iii. 1960, Y. Miyatake leg.

Paratypes: $11 \hat{\circ} 12$ \% , the same data as the holotype $(1 \hat{s} 19$ on slides). $6:$ $6 \%(161 \%$ on slides), the same locality as the holotype, $29-30$. iii. $1960 ; 1=25$. iii. $1959 ; 1 \%$ 23. x. $1959 ; 1 今$, 27. xii. 1959, T. Kawarabata leg. $1 \%$, Oyayama, Kuma. moto Pref., Kyushu, 31. xii. 1959, T. Kawarabata leg. 1\%, Hirao, Fukuoka city, Kyushu, 13. iv. 1958, Y. Miyatake leg. 1\%, Izuhara-Ariakeyama, Tsushima, 25. ix. 1959, Hidaka, Morimoto, Kamiya \& Kawarabata leg. 19 s. 9 9, Dogo, Matsuyama

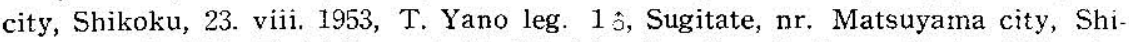

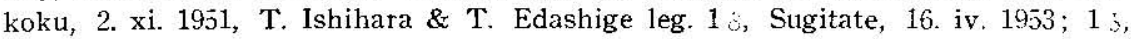
30. iii. 195ı, K. Sasaki leg.

Named in honor of Mr. Tenji Ue of Ohita Pref. who used to work on the biology of Psyllidae in Kyushu for a long time.

Host plant: unknown.

Differs from nigra Kuwayama in having the forewings ovate and shorter than twice as long as wide, and in having the dorsal valve of the female genitalia much longer than ventral; differs from granulosa Yu of Formosa in having the second marginal (medial), cell of the forewing much smaller than the first (cubital), and in having the prominent characters of both the male and the female genitalia as shown in figures.

\section{Key to the species of Metapsylla}

1 (4). Second marginal (medial) cell of forewing distinctiy shorter than first (cubital); posterior tibia with 6 apical spines (Japan)

2 (3). Forewing rather slender, distinctly longer than twice as long as wide; dorsal valve of female genitalia much longer than ventral

1. nigra Kuwayama

3 (2). Forewing ovate, without exception conspicuously shorter than twice as long as wide; dorsal valve of female genitalia shorter than ventral 
4(1). Second marginal (medial) cell of forewing much longer than first (cubital); posterior tibia with 5 apical spines (Formosa) 3. granulosa Yu

\section{Genus Psylla Geoffroy}

$P_{s y l l a}$ Geoffroy, 1762, Hist. Abr. ins. envir. Paris I: $482-498$.

Chermes Linné, 17j8, Syst. Nat. X: 453--455 (pro parte).

Psyllia Kirkaldy, 1905, Wien. Ent. Zeitg. 24: 268.

Brachypsylla Crawford, 1914, U. S. Nat. Mus. Bull. 85: 142 (pro parte):

Labicria Enderlein, 1918, Zool. Anz. 19: 348.

Asphagis Enderlein, 1921, Zool. Anz. 52: 120.

Asphagidella Enderlein, 1921, Zool. Anz. 52: 120.

Bacopelma Enderlein, 1926, Ent. Mitt. 13̄: 399.

Type-species: Psylla alni (Linné, 1758) (to be designated after Opinion 228 under the plenary powers of the International Commission of Zoological Nomen. clature, proposed by Eastop in 1963).

Head large, usually as wide as thorax or wider, more or less deflexed. Vertex depressed discally, varies in shape. Fyes large, hemispherical. Frons covered by genae, not visible (except for Psylla sasakii Y. Miyatake). Occiput covered by pronotum, not visible, sometimes visible laterally in caudal aspect. Genae always produced as more or less conical processes, often divergent, usually deflexed and depressed from plane of vertex. Antennae typically ten-segmented, slender, always longer than width of head, often much longer, with two basal segments stout, with segment III longest, with a pair of long setae at apex. Thorax robust, well arched. Pronotum more or less descending anteriorly, often vertical, not flat. Propleurites not equal at juncture with pronotum, pleural suture oblique, extending to posterior edge of pronotum, or proepimeron not extending to pronotum at all. Forewings membraneous, usually transparent, sometimes maculated or flavous, rounded apically, cubitus and media with a common basal petiole, pterostigma usually well defined and long, anterior margin with hairs, veins with microtrichiae (usually bi-seriately), Rs more or less sinuate, clavus almost reaching apex of $\mathrm{Cu}_{2}$. Posterior tibia often with a long or small basal spur, with five or six, black, apical spines. Proximal segment of posterior tarsi with a pair of black, apical spines. Meracanthus usually distinct, acute, projected ventro.caudad or caudad. Male proctiger usually simple, sometimes produced caudad. Dorsal valve of female genitalia usually broad basally and narrow or attenuate apically, longer than ventral.

\section{Psylla sasakii Y. Miyatake, sp. nov.}

(Fig. 3, A-D)

$\therefore:$ : General colour greenish brown to olive with olive-green markings on dorsum and vertex. Antennae yellowish brown, with three apical segments and tips of other segments black except for two basal segments, with two apical spines white. Eyes reddish brown; oceili yeliow. Apical spines of posterior tibia and proximal segment of posterior tarsi, tip of male proctiger black. Forewings hyaline, but somewhat flavescent, with veins yellowish brown.

Head conspicuously wider than thorax, not vertical: vertex small, short, much 
shorter than half as long as wide, rather raised along median line and at posterior ocelli, without conspicuous pubescense, narrowed anteriorly; genae produced as short blunt lobes, more or less conical, contiguous but somewhat depressed from plane of vertex, less than half as long as vertex on median line, distinctly pubescent, with a pair of long, stout setae ventrad outer-laterally, very widely separated at base; frons appearing as a distinct sclerite between genae in ventral aspect; occiput not visible; eyes more or less recessive; antennae long, slender, almost twice as long as width of head, with two apical setae of the same length, relative lengths of antennal segments as $3: 2: 10: 8: 7: 8: 7: 8: 4: 3$.
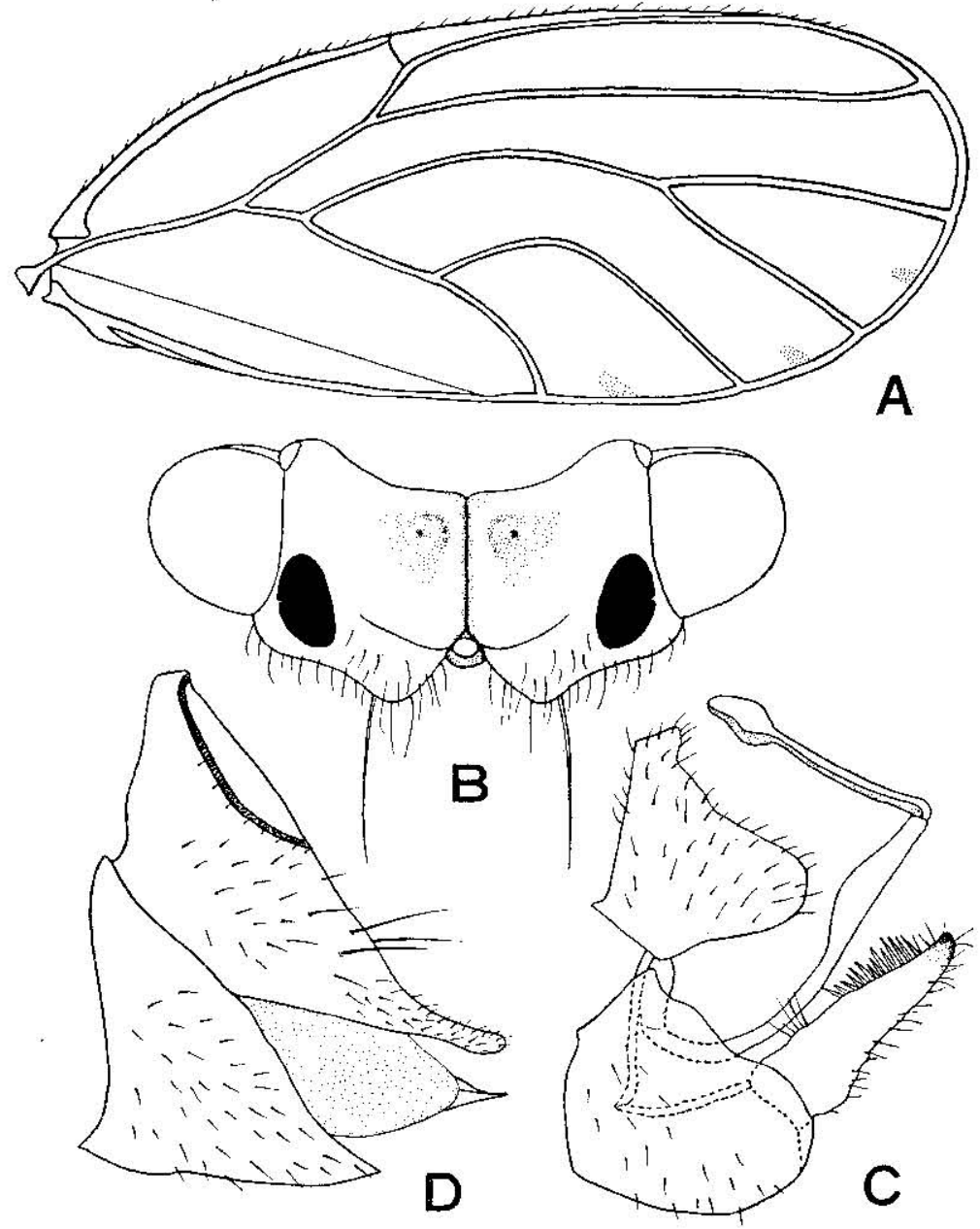

Fig. 3. Psylla sasakii Y. Miyatake, sp. nov.

A. Forewing, $\subsetneq$. B. Head (antennae excluded), frontal aspect, $\subsetneq$.

C. Male genitalia, lateral aspect. D. Female genitalia, lateral aspect. 
Thorax moderately arched, without pubescence; pronotum long, almost as long as vertex, nearly on same plane of vertex, broadly rounded anteriorly; scutum much shorter than wide, about $1 \times 2$; postnotum of metathorax markedly long, as long as vertex. Legs stout, with short pubescence; posterior tibia with a distinct basal spur, with 1 outer and 4 inner apical spines; proximal segment of posterior tarsi with a pair of apical spines dorsally; meracanthus rather long; acute at apex. Forewings broadly rounded at apex, 2.6 times as long as wide, not very much narrowed at base, with anterior margin sparsely pubescent; veins with microtrichiae; pterostigma long and narrow apically, almost reaching tip of Rs; R-stem a little thickened; Rs slightly sinuate, upturned at apex; M-stem strongly sinuate; $\mathrm{M}_{1+2}$ subequal in length to $\mathrm{M}_{3+4}$; $\mathrm{Cu}_{2}$ markedly long, distinctly longer than $\mathrm{Cu}$-stem, parallel to $\mathrm{Cu}_{1}$ in the apical two-thirds; $\mathrm{Cu}_{1}$ subparallel to $\mathrm{M}_{3+4}$; marginal cells very large, nearly equal, first marginal cell somewhat longitudinal-parallelogramy. Hindwings long, nearly reaching apex of forewings. Abdomen (excl. genital segments) rather short, slightly less than half as long as width of forewings, pubescent ventrally.

Male genital segments moderately large in lateral view; proctiger short. subtriangular, with anterior margin straight, rather oblique apically, strongly produced caudad basally as a posteriorly anguiate, lateral lobe: forceps long, as long as or longer than proctiger in lateral view, somewhat pyriform, broad basally, curved caudad, tapering to acute tip, with a small anterior lobe mesad ncar base. in caudal view slender, broad basally, gently arched, with tips incurved apically, the inner face with a patch of small setae in the basal half, with anterior margin beset with a series of strong setae; subgenital plate very low in lateral aspect, longer than high, about $11 \times 7$, somewhat kidney-shaped, with dorsal margin sinuate; aedeagus long, with first segment broadened near apex and almost twice as long as second segment which is thickened in the apical one-third. Female genital segments large, almost as long as the rest of abdomen, with long pubescence; dorsal valve distinctly longer than ventral, somewhat attenuate in apical portion, with apex rounded and upturned, with four pairs of long hairs.dorsad near midpoint; ventral valve stout, with dorsal and ventral margins sinuate, acute apically; inner valve sharp, much longer than dorsal valve: anus rather large, 0.8 times as long as the rest of dorsal valve in larger diameter.

Length of body $1.6-1.7 \mathrm{~mm}, 1.9-2.0 \mathrm{~mm}$; length of forewing $2.0-2.1 \mathrm{~mm}$, > $2.2-2.4 \mathrm{~mm}$; length of antenna $31.3-1.5 \mathrm{~mm},-21.4-1.5 \mathrm{~mm}$.

Distribution: Japan (Shikoku, Honshu).

Holotvpe (3): Mt. Ishizuchi, Ehime Pref., Shikoku, 3. ix. 1953, K. Sasaki leg.

Paratypes: $6: 12 \div$, the same data as the holotype ( $2 \div 1 \div$ on slides). 13 6. , Omogokei, Ehime Pref., Shikoku, 6. ix. 1953, K. Sasaki leg. ( 1 on slide). 1\%, Omogokei, Ehime Pref., Shikoku, 7. viii. 1953 , T. Yano leg. $55892 \%$, Ina, Nagano Pref., 16. vii. 1961, Y. Maeta leg.

Named for Mr. Kota Sasaki of the former staff at the Entomological laboratory. College of Agriculture, Lhime University, in recognition of his contribution to the study of Psyllid fauna in Japan.

Host plant: "Nemunoki"-Albizzia Jutibrissin Durazz. [Leguminosae]. nymphs \& adults, confirmed at Ina, Nagano Pref. in July, 1961 by Y. Maeta.

This species differs from other typical members of the genus in the short genal cones which are swollen beneath into two more or less conical processes 
but widely separated at the base as occurring in the Pauropsyllinae, so that the frons appears as a distinct sclerite between them on the frontal aspect. However, the sum total of its characters indicates unmistakably that it belongs to the genus. It may remain in the genus Psylla until a survey of the entire genus as now understood reveals more adequate reasons for subdivision.

This species is somewhat similar to Psylla (Acizzia) spp. from New Zealand (see Tuthill; 1952) in the wing venation and the shape of the male proctiger, but differs from them in entire lacking of wing maculations or a hook-like secondary lobe on the posterior margin of the male proctiger. It might be too early to discuss the relationships between this species and New Zealand species now, unless some more other species are obtained.

It is worthy noting that this species was found with $P$. jamatonica Kuwayama on the same tree (Albizzia Julibrissin) at the same time in July, 1961 (in Ina, Nagano Pref.) by Y. Maeta. However, this species is easily distinguishable from the latter in being larger, in having the antennae distinctly longer and fully twice as long as the width of head (less than 1.5 times in jamatonica. Kuw.), genal cones widely separated at the base and continuous from vertex (well-defined from vertex, though shorter than half as long as vertex in jamatonica Kuw.), frons visible and appears as a distinct sclerite between the vertex.

\section{Psylla magnifera Kuwayama}

Psylla mesnifera Kuwayama, 1908, Trans. Sapporo Nat. Hist. Soc. 2: 170.

Distribution: Japan (Hokkaido, Honshu).

Type-series cxamined: $1: 1 \%$, Hokkaido, S. Matsumura leg. (preserved in the Entomological Institute of Hokkaido University).

Host plant: "Hannoki" Alnus japonica Steud. [Betulaceae]; Matsumura, 1917: 372 .

\section{Psylla alni (Linne)}

Chermes alni Linné, 1758, Systema Naturae X: $4 \vec{\jmath} 4$.

Psylla alni Linné, 1773, DeGeer Mem. I, III: 148.

Clethropsylla alni Amyot, 1847, Ann. Soc. Ent. Fr.: $4 \bar{\jmath} 9$.

Psylla fuscinervis Förster, 1818, Verh. natur. Ver. preuss, Rhein. 3: 70.

Psylla heydeni Förster, 1848, Verh. natur. Ver. preuss. Rhein. 3: 81.

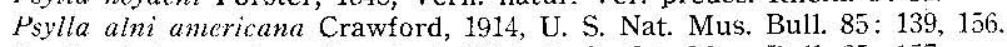

Psylla alni gossypiona Crawford, 1914, U. S. Nat. Mus. Bull. 85: 157.

Psyllia alni americana: Van Duzee, 1917, Cat Hemip. N. Am.; 811.

Psyllia alni americanella Strickland, 1939, Can. Ent. 71: 211.

Distribution: Japan (Hokkaido, Honshu), N. America, Europe, Russia, Saghalin. Specimens examined: Many examples from the following localities:

Hokkaido: Aizankei (vii, Y. Miyatake); Ashoro (vii, H. Kuroko, K. Yano, K. Morimoto, Y. Miyatake); Akan (viii, R. Matsuda); Mt. Daisetsu (vii, K. Sasaki, T. Kawarabata, Y. Miyatake); Obihiro (viii, R. Matsuda); Nukabira (vii, K. Morimoto, T. Kawarabata; viii, Y. Miyatake); Meakandake (vii, Y. Miyatake); Sounkyo (vii, K. Sasaki); Sapporo (viii, Y. Miyatake); Yuohzan (viii, K. Yano). Nagano Pref.: 6.s, 7-1t. vii. 1959, K. Morimoto leg.; 1\%, 5. viii. 1959, S. Miyamoto leg. ; Karuizawa. 3 , Mt. Nyuhgasa, 30. vii. 1962, K. Morimoto leg. 
Yamanashi Pref.: $1 \leqslant 2 \varsigma$, 25. vii. 1959, S. Miyamoto leg; $1 \vdots 19,2$. viii. 1959 , Y.

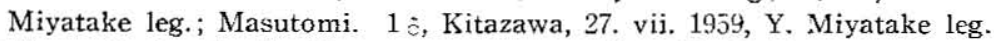

Ishikawa Pref.: 1s 1:, Hakusan, 29-31. viii. 1960, T. Hidaka leg.

(The Japanese specimens were compared with the European ones with Dr. Eastop's favour of the British Museum (Natural History).)

Host plants: "Hannoki"--Alnus juponica Steud. [Betulaceae]; adults, confirmed at Masutomi, Yamanashi Pref. in August, 1959 by me. "Keyama-hannoki" -.*Alnus hirstuta Turcz. [Betulaceae]; nymphs \& adults, confirmed at Aizankei, Hokkaido in July, 1922 by me; adults, confirmed at Nukabira, Hokkaido in August, 1962 by me.

\section{Psylla omogoensis Y. Miyatake sp. nov.}

(Fig. 4, A-.D)

A: General colour greenish brown; antennae light brown except two apical segments dark brown; eyes dull brown; ocelli yellow; forewings hyaline; veins light brown; apical spines of posterior tibia and tarsi black; abdomen and genital segments greenish; forceps black at apex.

Head rather small, deflexed, nearly as wide as thorax; vertex slightly over

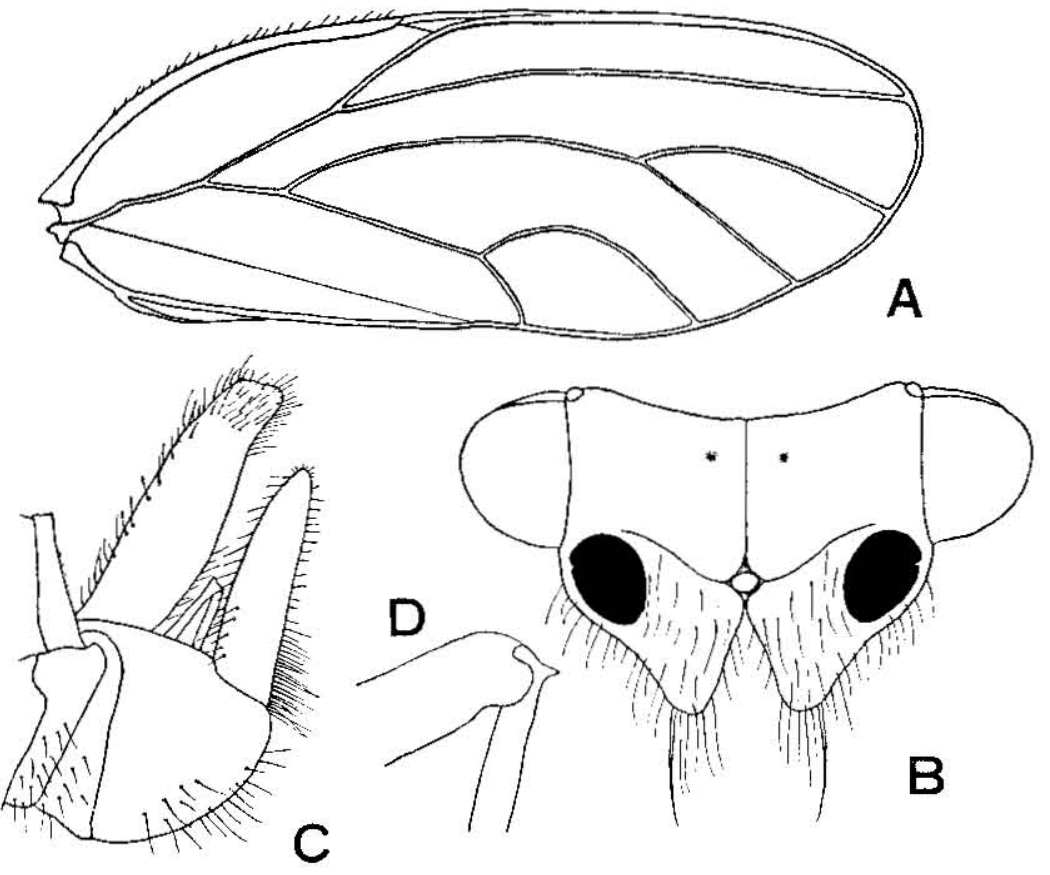

Fig. 4. Psylla omogocnsis Y. Miyatake, sp. nov.

A. Forewing, +. B. Head (antennae excluded), frontal aspect, \&.

C. Male genitalia, lateral aspect. D. Basal spur of posterior tibia,. 
hall as long as broad, gently impressed discally, with posterior margin incised not pubescent; genal cones cone-shaped, shorter than vertex on median line, vertical, divergent, blunt apically, conspicuously pubescent, with a pair of long setae at outer side of apex; occiput not visible; antennae slender, long, ovet twice as long as width of head, with two short apical setae, with first segment robust, reiative lengths of the antennal segments as $2: 2: 12: 5: 5: 5.5: 5: 2: 1: 1$.

Thorax broad, arched, without pubescence; pronotum comparatively large, almost as long as genal cones, convex; praescutum 1.7 times as long as pronotum. scutum rather long, about half as long as wide, rather flat dorsally, concave betwcen scutum and scutellum; scutellum large, nearly as long as pronotum. trapezoidal. Legs massive, pubescent; posterior tibia with a short basal spur (Fig. 1, D), with 2 outer and 3 inner apical spines; proximal segment of posterior tarsi with a pair of apical spines. Forewings long, elongate, over $2 . \overrightarrow{0}$ times as long as broad; pterostigma conspicuously weak, rudimental, shorter than Cu. anterior margin with long hairs almost to tip; veins with numerous microtrichiae. Rs long, parallel with anterior margin, almost reaching tip, not upturned api. cally; second marginal (medial) cell long, much larger than first (cubital), sub. quadrilateral; $\mathrm{Cu}_{1}$ and $\mathrm{M}_{1+2}$ well arched; $\mathrm{M}_{3+4} 2.4$ times as long as $\mathrm{Cu}_{2}$. Abdomen (excl. genital segments) short, shorter than posterior tibia, with tergites bare and sternites sparsely hairy.

Male genital segments very large in lateral aspect; proctiger slightiy tapering apically, with long pubescence dorsally, with posterior margin sinuate; forceps long, slightly shorter than proctiger (21:25), in lateral view parallel margined in the basal half, and tapering regularly to blunt apex, in caudal view slender. gently arched to acute apex; the inner face beset with numerous, retrorse, white hairs, more dense and longer in the basal half; subgenital plate as high as forceps, hairy in the apical half, with sinuate dorsal margin as shown in figure.

$\because$ : unknown.

Length of body $52.8 \mathrm{~mm}$; length of forewing $34.1 \mathrm{~mm}$; length of antenna $2.1 \mathrm{~mm}$

Holotype (亡): Omogokei, Iyo (Ehime Pref.), Shikoku, 5. vi. 1952, T: Yano leg.

Host plant: unknown.

Differs from buxi (Linné) in having the antennae distinctly longer than twice as long as the width of head, the first marginal cell not higher than wide, and in having the forceps more slender and tapering to blunt apex in lateral aspect.

\section{Psylla morimotoi Y. Miyatake sp. nov.}

(Fig. 5, A-D)

\% : General colour light to fresh green; thorax rather brownish and with irregular markings of reddish brown; abdomen and genital segments more greenish except for apical portion of forceps dark brown. Antennae brown, with two basal segments green, with two apical segments and tips of remaining segments black. Eyes brown; ocelli yellow to orange. Forewings more or less flavous or lightly greenish, with veins green. Apical spines of posterior tibia and proximal segment of posterior tarsi black.

Head large, slightly wider than thorax, vertical, slightly below plane of pro. notum-; vertex moderately large in size, half as long as wide on median line. 
with posterior margin rather incised, produced anteriorly near frons as figured, pubescent anteriorly; antennal socket not very much swollen; genal cones stout, as long as vertex or shorter, less divergent, almost as long as wide, obliquely truncate apically, pubescent, below plane of vertex; occiput not visible; frons well covered with vertex, not visible; eyes slightly recessive; antennae long, slender, over 2.4 times as long as width of head, pubescent, with two apical setae of the different length (one long and the other half), relative lengths of the antennal_segments as $5: 3: 12: 11: 11: 13: 14: 13: 5: 4$.
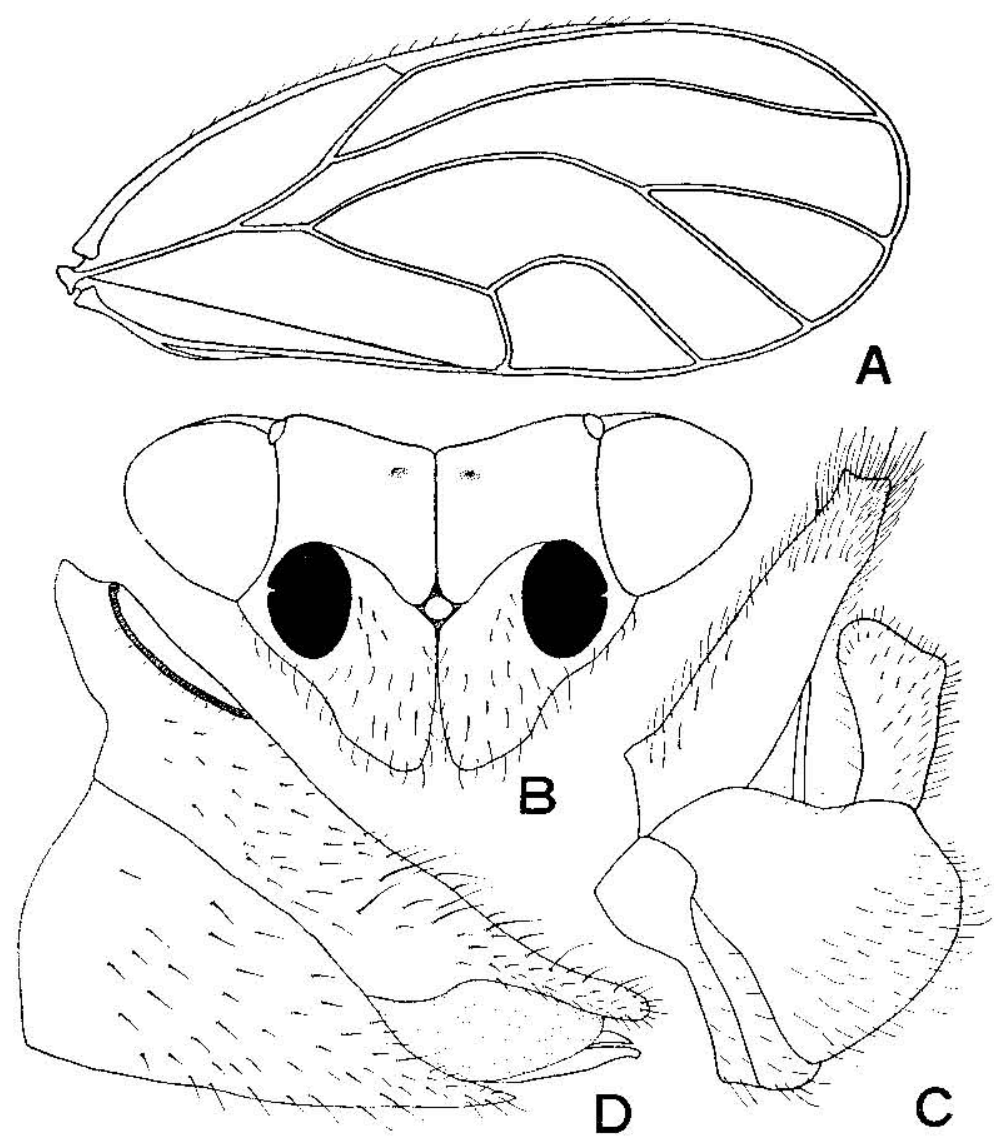

Fig. 5. Psylla morimotoi Y. Miyatake, sp. nov.

A. Forewing, o. B. Head (antennae excluded), frontal aspect, $\%$.

C. Male genitalia, lateral aspect. D. Female genitalia, Iateral aspect.

Thorax robust, arched, slightly rugose, not pubescent; pronotum well arched, convex anteriorly, with two lateral impressions, with posterior margin almost straight; praescutum wider than pronotum, somewhat crab-shell like, less than half as long as wide; scutellum rectangular, about half as long as wide: Legs 
rather slender, densely pubescent; posterior tibia with a distinct and slightly retrorse basal spur, with 2 outer and 3 inner apical spines; proximal segment of posterior tarsi with a pair of apical spines; meracanthus moderately long, two times as long as wide, retrorse. Forewings long, elongate, 2.3 times as long as wide; pterostigma distinct but short, never reaching apex of $R 5$, closed basally: Rs nearly parallel with anterior margin; $M$ well sinuate; $\mathrm{M}_{3+4}$ subparallel with $\mathrm{Cu}_{1} ; \mathrm{Cu}_{1}$ and $\mathrm{Cu}_{2}$ not parallel to each other; relative length of $\mathrm{Cu}$ and $\mathrm{Cu}_{2}$ 16:7; first marginal (cubital) cell broad, wider than high, about $3 \times 2$; second marginal (medial) cell elongate, triangular, about $2 \times 1$, longer than first; hindwings much shorter than forcwings. Abdomen (excl. genital segments) short, as long as width of head, sparsely pubescent.

Male genital segments huge, denseiy pubescent; proctiger slender, with both margins straight, narrowed at apex, much longer than furceps (almost twice as long as forceps); forceps in lateral view stout, short, narrow basally, enlarged apically, produced anteriorly as figured, obliquely truncate at apex, in caudal view heavy, arched, with inner surface beset with numerous, short, retrorse hairs, in dorsal view with each apical margin slightly curved, more or less serrate, and strongly sclerotized as a narrow rim; subgenital plate small, much lower than proctiger, rounded ventrally, with dorsal margin sinuate. Female genital segments large, as long as the rest of abdomen, denseiy pubescent; dorsal valve much longer than ventral, large basally, narrowed and sinuate in apical third, with tip blunt and horizontal, with dorsal margin not curved; anus less than half as long as the rest of dorsal valve in larger diameter in lateral aspect; inner valve nearly as long as dorsal valve, longer than ventral; ventral valve broad basally, shar, acute and slightly upturned apically, with dorsal margin sinuate.

Length of body $2.3 \mathrm{~mm}, 3.1-3.2 \mathrm{~mm}$ (to tip of folded wings $4.4 \mathrm{~mm},-4.5$ $4.8 \mathrm{~mm})$; length of forewing $3.6 \mathrm{~mm}, 4.0-4.1 \mathrm{~mm}$; length of antenna $: 2.1 \mathrm{~mm}$, $2.3-2.4 \mathrm{~mm}$.

Distribution: Japan (Honshu).

Holotype (3): Kanayama, Masutomi, Yamanashi Pref., Honshu, 2. viii. 195 , Y. Miyatake leg.

Paratypes: 19, the same data as the holotype. 19, Hirokochi, nr. Narada Yamanashi Pref., Honshu, 31. vii. 1959, Y. Miyatake leg. 1\%, (on slide), Karuizawa, Shinano (Nagano Pref.), 7-14. vii. 1959, K. Morimoto leg. 2 , Mt. Tanigawa. Gunma Pref., 23. vii. 1961, T. Kawarabata leg.

Host plant: unknown.

Differs from alni (Linné) in being rather smaller, in having the genal cones very prominent and less divergent, and the antennae not wholly black, and in having the dorsal valve of the female genital segments not longer than the rest of the abdomen nor very much longer than the ventral valve. Differs from abicti Kuwayama in being larger, in having the antennae almost 2.1 times as long as the width of head (less than 2 times in case of abieti Kuw.), and in having the dorsal valve of the female genital segments as long as (half as long as in abieti Kuwayama) the rest of the abdomen and the forceps of male genital segments not slender but enlarged apically in lateral view. Differs from amakusensis Kuwayama in having the first marginal (cubital) cell wider than long and the forceps not tapering but enlarged apically in lateral aspect. and in having the dorsal valve of the female genital segments subacute. 


\section{Psylla hexastigma Horváth}

Psylla hexastigma Horváth, 1899, Termes. Füzetek 22: 373.

Distribution: Japan (Hokkaido, *Honshu, Shikoku, *Kyushu), Siberia.

Specimens examined: 6 今5 6,9, Sapporo, 14. vii. 1953, K. Sasaki leg. 23 , Sounkyo, 17. vii. 1953, K. Sasaki leg. 1 1\%, Mt. Daisetsu, 19. vii. 1957, K. Sasaki leg. 605199 , Kurodake, Mts. Daisetsu (on snow valley), 21-22. vii. 1962, Y Miyatake leg. 2 3 $3 \%$, Ashoro, 27-28, vii. 1962, Y. Miyatake leg. 2 \%, 25-27. vii. 1959. T. Kawarabata leg.; 5 sj 3 Miyatake leg.; $1 \lesssim 2 \$$, 4-5. viii. 1962, Y. Miyatake leg.; Nukabira, Tokachi, Hokkaido. 1\%, Okubo, Jinryo-mura, Awa, Shikoku, 20. ii. 1953, I. Hiura leg. 1 . Saragamine, Iyo, Shikoku, 22. viii. 19j4, M. Miyatake leg. 1 ?, Hachimantai, Akita Pref., 12. vii. 1962, Y. Miyatake leg. 1\%, Sakasamaki, M. Echigo, 2. vii. 195̄6, K. Baba leg. 19, Kôrasan, Fukuoka Pref., 21. vi. 1952, 1. Hiura leg.

Host plants: Hydrangea spp. [Saxifragaceae]; Kuwayama, 1932: 1815.

\section{Psylla betulae (Linné)}

Chermes betulae Linné, 1761, Fauna Suecia, Nr. 1007.

Pyylla zetterstedli (Thomson, 1877), Opusc. Ent. Fasc. 8: 832 (Chermes).

Distribution: Japan (Hokkaido, Honshu), Europe, Russia.

Specimens examined: $1 \%$, Noboribetsu, Hokkaido, 18. vi. 190t, S. Matsumura leg. $2 ; 2$; , Toyohira, Sapporo, 1. vi. 1893, S. Matsumura leg. (preserved in the Entomological Institute of Hokkaido University).

\section{Psylla midoriae Y. Miyatake, sp. nov.}

(Fig. 6, A-D)

$\hat{2}:$ : General colour orange to red; antennae red, with two apical segments and tips of remaining ones black; eyes brown; genal cones orange yellow; forewings opaque, dark brown; apical spines of posterior tibia and proximal segment of posterior tarsi black.

Head small, as wide as thorax, deflexed; vertex distinctly longer than half as long as broad on median line, nearly plane, in frontal view, upper margin incised; occiput not visible; genal cones short, as long as vertex, stout, nearly as long as broad, contiguous on inner margin, blunt apically, pubescent scatteringly; frons reduced, not visible; antcnnae short, twice as long as width of vertex, rather stout, with two apical setae of different length, relative lengths of the antennal segments as $2.5: 2: 5: 4: 3: 4: 4: 3: 2: 2$.

Thorax not strongly arched, more or less flat dorsally, without pubescence : pronotum as long as genal cones, anteriorly arched, vertical; praescutum short, less than half as long as broad; scutum short, about $3 \times 7$; scutellum subtrapezoidal. Legs stout, pubescent; posterior tibia with a minute, tubercular, basal spur, with 1 outer and 3 inner apical spines; proximal segment of posterior tarsi with a pair of apical spines. Forewings moderately long, about 2.2 times as long as wide, broadly rounded apically; veins with microtrichiae; pterostigma well defined and basally closed; Rs more or less sinuate, parallel with $R_{1}$; first marginal (cubital) cell very high, almost as high as second (medial), somewhat parallelo- 
gramy; $\mathrm{Cu}_{1}$ and $\mathrm{Cu}_{2}$ parallel to each other; relative lengths of the veins $\mathrm{Cu}, \mathrm{Cu}_{2}$, $\mathrm{M}_{3+4}$ as $17: 13: 25$. Abdomen (excl. genital segments) very short, less than width of head, shorter in male, with bare tergites and sternites sparsely pubescent.

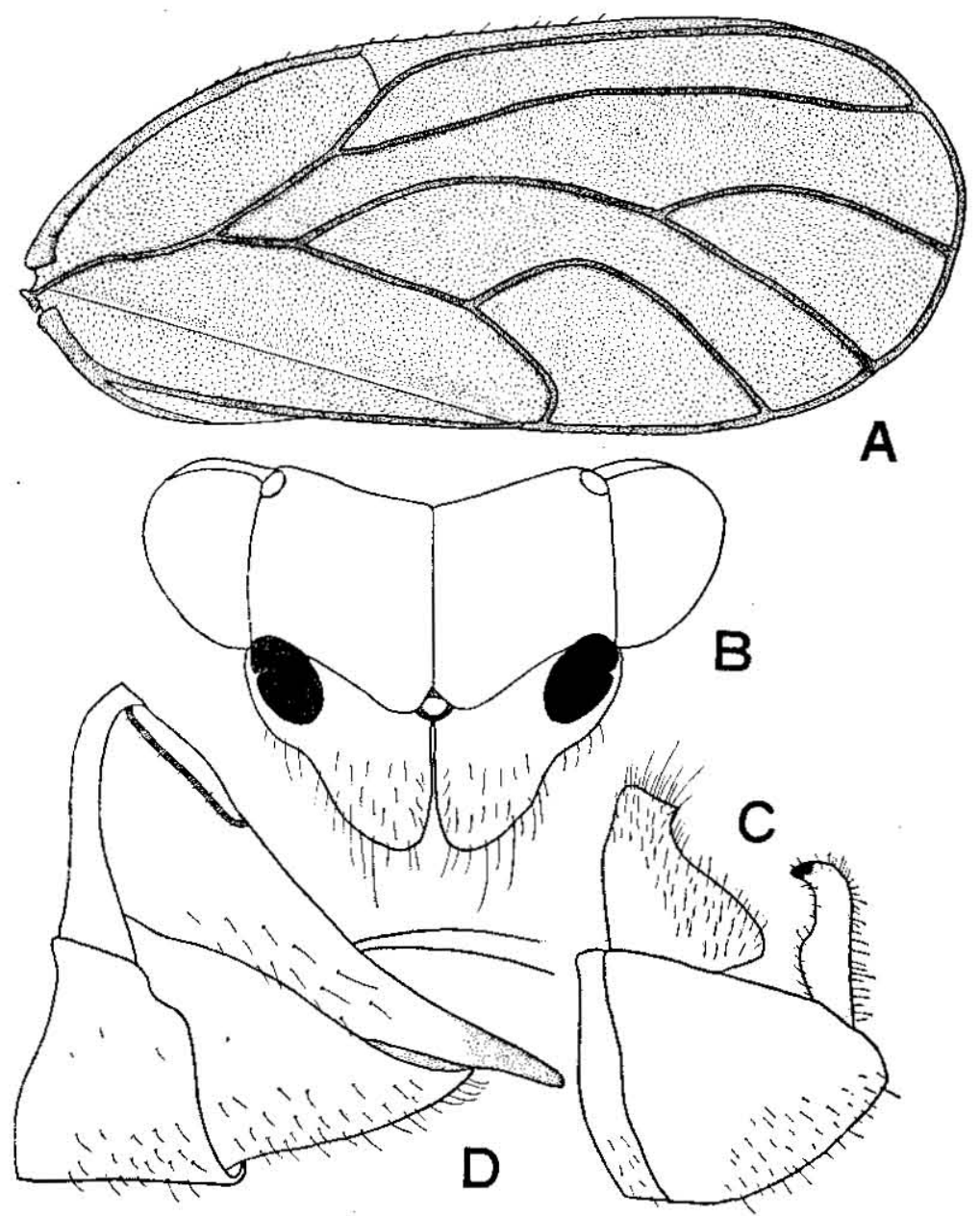

Fig. 6. Psylla midoriae Y. Miyatake, sp. nov.

A. Forewing, $5 . \quad$ B. Head (antennae excluded), frontal aspect, 3 .

C. Male genitalia, lateral aspect. D. Female genitalia, lateral aspect.

Male genital segments in profile moderately large; proctiger stout, short, as long as forceps, slightly curved caudad apically, pubescent, strongly produced caudad as a large lobe as figured; anus opened posteriorly; forceps slender in profile, apically curved cephalad, bluntly acute apically, in caudal aspect slender, regularly tapering to acute apex, gently curved mesad, inner face with long, 
retrorse setae; subgenital plate large in lateral view, almost twice as high as proctiger, somewhat equilateral triangular, with dorsal margin sinuate, sparsely pubescent in the apical half. Female genital segments slightly shorter than the rest of abdomen; dorsal valve long, slender, much longer than ventral, apical portion attenuate, subacute and without conspicuous pubescence, with two long hairs dorsad near midway; ventral valve small, rather triangular in profile, a little upturned and acute apicaliy, pubescent ventrally, with ventral margin slightly sinuate.

Length of body $\hat{\imath} 1.7 \mathrm{~mm}$, $1.8 \mathrm{~mm}$; length of forewing $\leqslant 2.3 \mathrm{~mm}, 2.2 \mathrm{~mm}$; length of antenna $\delta 1.0 \mathrm{~mm}, 0.8 \mathrm{~mm}$.

Distribution: Japan (Shikoku).

Holotype (s): Jyôju-sha, Mt. Ishizuchi, Ehime Pref., Shikoku, 24. vii. 1958, Midori Udaka (Miss) leg.

Paratype: 19, Iwaya nr. Kuma, Ehime, Pref., Shikoku, 2. viii. 1955, K. Sasaki leg.

Host plant: unknown.

Differs from coccinea Kuwayama in having the antennae short and 1.3 times as long as the width of head (1.8 times in coccinca Kuw.), the genal cones entirely contiguous instead of divergent, the cubital cell of forewing much longer as figured, the proctiger of male genitaria short and strongly produced caudad as a large, secondary lobe and the forceps much more slender, the dorsal valve of the female genitalia strongly attenuate and much exceeding ventral valve, although similar in coloration.

\section{Psylla amakusensis Kuwayama, Jr.}

Psylla umakusensis Kuwayama, Jr., 1939, Zool. Mag. 51: 535, fig. 1-5 (Amakusa, Kyushu).

Distribution: Japan (*Honshu, *Shikoku, Kyushu).

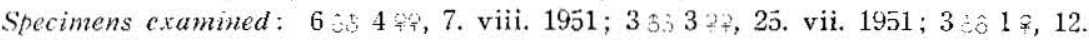
viii. 1955; Kòrasan, nr. Kurume, Kyushu, S. Miyamoto leg. 1\%, Omogokei, Iyo, Shikoku, 14. vii. 1952, S. Miyamoto leg. 10 , 22. vii. $1947 ; 1 \neq 1$. vii. 1950 ; Murozumi, Yamaguchi Pref., S. Miyamoto leg.

Type-stries examined: Holotype ( $)$ and allotype ( $(2)$ from Amakusa, in the Entomological Laboratory, Kyushu University.

Host plant: unknown.

\section{Psylla viburnii F. Löw}

Psylla viburnii Löw, 1876, Verh. zool.-bot. Ges. Wien 26: 191, 195.

Psylla viburnii Shinji, 1942 (nec F. Löw, 1876), Ins. World 46: 2. (nom. praeocc.)

Distribution: Japan (Honshu, *Kyushu).

Specimens examined: 533729 , Hachimantai, Akita Pref., 11. vii. 1962, Y Miyatake leg. $8035 \%$, 30. v. 1944, Esaki \& Yasumatsu leg.; $9302 \% 9,13$. v. 1953 , Esaki, Yasumatsu \& Hirashima leg.; Hikosan, Fukuoka Pref. 153020 \%, 10. v. 1928, S. Hashimoto leg.; 19, 10. v. 1929, S. Hashimoto leg.; 161 ㅇ, 10. iv. 1959 , Y. Miyatake leg.; 26 >5 $25 \%$, 11. v. 1959, Y. Miyatake leg.; Mt. Kujuh, Ôita Pref.

Host plants: "Mushikari"-_Viburnum furcatum Blume [Caprifoliae]; adults, confirmed at Hachimantai, Akita Pref. in July, 1962 by me; adults \& nymphs, 
confirmed at Mt. Kujuh, Ôita Pref. in April \& May, 1959 and Mt. Sangun, Fukuoka Pref. in March, 1960 by me. "Gamazumi"-Viburnum dilatatum Thunb. [Caprifoliae]; nymphs \& adults, Shinji, 1942: 3.

\section{Psylla fulguralis Kuwayama}

Psylla fulguralis Kuwayama, 1908, Trans. Sapporo Nat. Hist. Soc. 2: 177, p1. 3, fig. 17 (Honshu).

Distribution: Japan (Honshu, Shikoku, *Kyushu, Yakushima), Ryukyu.

Specimens examined: 1 \& 1 o, Mt. Nonobori, Mie Pref., 14. v. 1958, H. Ichihashi leg. 5 ồ 7 \% , Murozumi, Yamaguchi Pref., 29. iv. 1948, S. Miyamoto leg. 253 3 3 ํㅜ, Mt. Sara, Iyo, 26. iv. 1953, K. Sasaki leg. $1 \%$, Sugitate, nr. Matsuyama, 16. iv. 1953, K. Sasaki leg. 2 Kashima, nr. Matsuyama, 3. vi. 1954, K. Sasaki leg. I , Mt. Takanawa, Iyo, 3. v. 1951, M. Miyatake leg. $1 \delta 4$ ำ, Futagami I., Ehime Pref., 29. iv. 1957, F. Takechi leg. 1ઈ, Tsuwaji I., Ehime Pref., 28. iv. 1957, F. Takechi leg. 1 1 , Murotozaki, Tosa, 8. vi. 1959, S. Hisamatsu leg. 2 Sanuki, 1-2. v. 1958, Y. Miyatake leg. 1\%, Izuhara-kuda, Tsushima, 26. iii. 1930, H. Hori leg. $2 \delta_{2}$ Okinoshima, Chikuzen, $2 \overline{5}-28$, vii. 1958, Hirashima, Murakami \& Miyatake leg. 654 , Mt. Sefuri, nr. Fukuoka, 22. ii. 1958, Y. Miyatake leg. $3 \mp$, Mizunashi, nr. Fukuoka, 15. v. 1958, Y. Miyatake leg. 5 5 5 , Mt. Kanayama, nr. Fukuoka, 15 v. 1958 , Y. Miyatake leg. $7: 55$ \%, Mt. Fukuchi, nr. Kokura, 5. v. 1962, Y. Miyatake leg. $2 \%$, Innaki, nr. Fukuoka, 20. iv. 1958, Y. Miyatakc leg. 5 tic 3 . . Tsuda, Kokura, 22. iii. 1958, Y. Miyatake leg. 1 , Tomioka, Amakusa, 13. v. 1960 , K. Morimoto leg. 1 , Ôdomari, Satsuma, 2. iv. 1959, Y. Maeta leg. 1 , 1. v. 1962, F. Nakasuji leg.; 1 o , 22. v. 1962, M. T. Chûjo leg.; 1 j, 31. v. 1958, K. Yano leg.; 1 1 1 , 29. vi. 1953, I. Hiura leg.; Cape Sata, Kagoshima Pref. 1 is, Ambo-Funayuki, Yakushima, 7. viii. 1929, H. Hori leg. 1 , Shirahama, Iriomote I., 1. iv. 1962, S. Tamai leg.

Type-series (j) from Kamakura were examined (preserved in the Entomological Institute of Hokkaido University).

Host plants: "Tsurugumi"-_*Elaeagnus glabra Thunb. [Elaeagnaceae]; adults \& nymphs, confirmed at Mt. Sefuri, Fukuoka Pref. in February, 1958 and Mt. Fukuchi, nr. Kokura in May, 1962 by me. "Marubagumi"-*Elaeagnus macrophylla Thung. [Elaeagnaceae]; adults, confirmed at Murozumi, Yamaguchi Pref. in April, 1948 by S. Miyamoto. "Nawashirogumi"--*Elaeagnus pztngens Thunb. [Elaeagnaceae]; adults, confirmed at Mizunashi, nr. Fukuoka in May, 1958 and Mt. Zoozu, Sanuki in May, 1953 by me; adults, confirmed at Mt. Sara, Ehime Pref. in April, 1953 by K. Sasaki.

\section{Psylla yasumatsui Y. Miyatake sp. nov.}

(Fig, 7. A - C)

\%: General colour reddish brown; antennae light brown except one apical segment black; eyes dark brown; ocelli red; genal cones usually yellowish brown, sometimes greenish; forewing subhyaline, with a continuous, broad band of dark brownish colour from the apex along the apical half of the posterior margin, $\mathrm{Cu}_{2}, \mathrm{Cu}$ and $\mathrm{M}+\mathrm{Cu}$; veins yellowish brown; abdomen light brown to green, with the apical half of the genital segments dark brown. 
Head scarcely narrower than thorax, strongly deflexed; vertex shorter than half as long as broad, rather flat, with posterior margin incised; genal cones short, as long as vertex, blunt apically, stout, as long as broad, sparsely pubescent, slightly divergent; antennae slender, nearly twice as long as width of vertex.

Thorax broad, robust, protuberant; pronotum anteriorly arched and somewhat deflexed perpendicularly, nearly on the same plane of vertex; praescutum large, about $19 \times 8$; scutum broad, about $11 \times 5$; scutellum somewhat trapezoidal. Legs stout; posterior tibia with a short basal spur, with 4 outer and 1 inner black apical spines; proximal segment of posterior tarsi with a pair of black spines at apex. Forewings somewhat rhomboidal, over twice as long as wide, with anterior margin sparsely pubescent; pterostigma distinct and long, almost reaching the apex; Rs more or less sinuate; Cu quite straight; first marginal (cubital) cell small and rhomboidal, much smaller than second (medial); Cu over three times as long as $\mathrm{Cu}_{2} ; \mathrm{M}$ well arched. Abdomen (excl. genital segments) short, nearly as long as ventral valve of genital segments, with tergites bare and sternites distinctly pubescent.

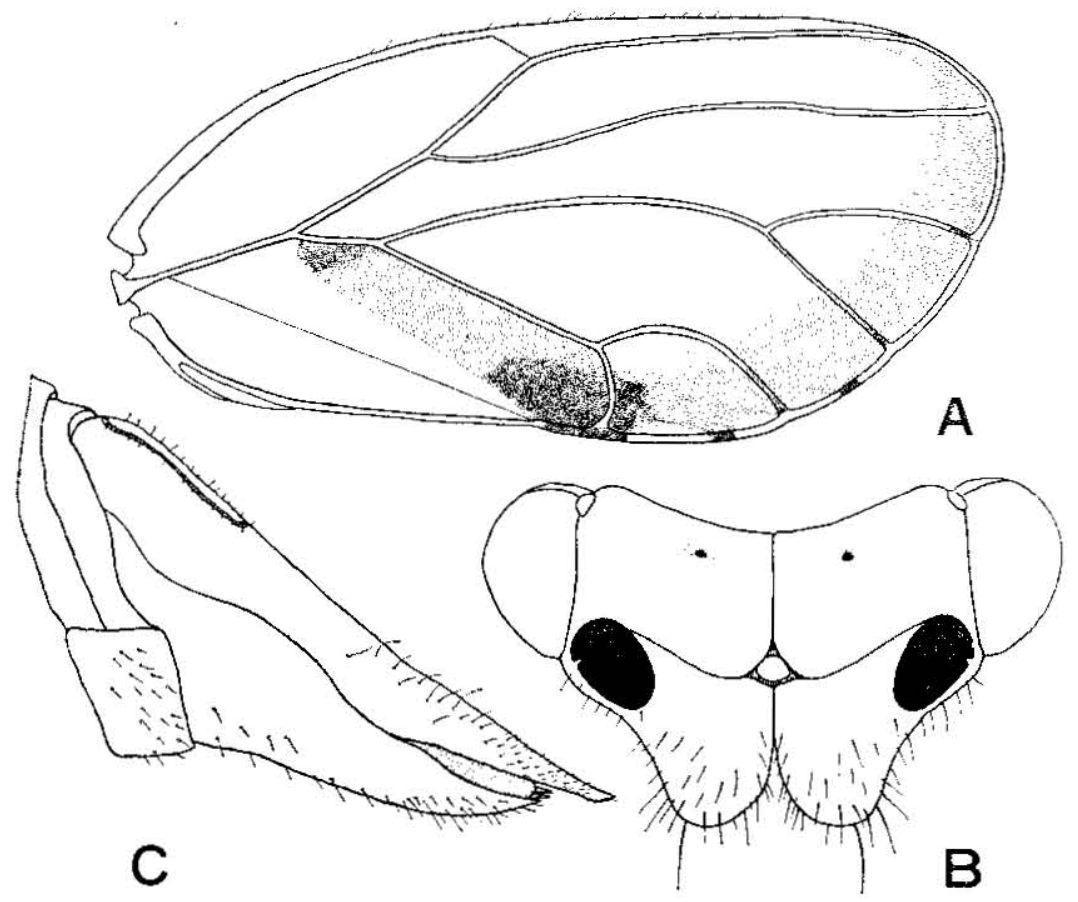

Fig. 7. Psylla yasumatsui Y. Miyatake, sp. nov.

A. Forewing, 8. B. Head (antennae excluded), frontal aspect, 4.

C. Female genitalia, lateral aspect.

Female genital segments large, in lateral view exceedingly long, over as long as thorax; dorsal valve much longer than ventral, slender, acute apically, with apex slightly upturned, sparsely pubescent dorsally, with dorsal margin nearly 
straight to apex in lateral aspect; ventral valve gently upcurved in lateral aspect, acute, dorsal margin sinuate, pubescent ventrally.

ڤิ: unknown.

Length of body $4.0-4.1 \mathrm{~mm}$; length of forewing $3.8-4.4 \mathrm{~mm}$; length of antenna $\$ 1.4-1.5 \mathrm{~mm}$.

Dislribution: Japan (Kyushu, Honshu).

Holotype () : Hikosan, Fukuoka Pref., Kyushu, 7. vi. 1959, Y. Miyatake leg.

Paratypes: 19, Hirokochi, nr. Narada, Yamanashi Pref., Honshu, 31. vii. 1959, Y. Miyatake leg. 1\%, Mt. Hikosan, Buzen (Fukuoka Pref.), 2. viii. 1937, Hori, Fujino, \& Kawahara leg.

The name of this new species is dedicated to honor of Prof. Keizo Yasumatsu.

Host plant: “Kuma-shide"-Carpinus japonica Blume [Betulaceae] (?).

Differs from any other species of the genus in Japan in having the prominent. marginal band of brownish colour on the forewing. In this character this species is somewhat similar to Psylla spadica Kuwayama of Formosa, but differs from it in being much larger, in having the genal cones not conical but broad and not divergent but contigous, the vertex distinctly shorter than half as long as wide, the marginal cells not slender but very wide, the female genitalia markedly Iong, nearly twice as long as the rest of the abdomen (compared with the type-speci. men of Psylla spadica (3) in the Entomological Institute of Hokkaido University in 1962).

\section{Psylla malivorella [Sasaki]}

(Fig. 8, A-D)

Psylla malivorella [Sasaki], 1915, Byo-tyugai Zasshi 2: 301--304.

E?: General colour yellow to orange, more or less greenish in the newly. emerged form, dark brown with black markings in the over-wintered form; antennae brown, with two basal segments yellowish brown, with tips of each segment from III to VIII and two apical segments black; eyes reddish to dark brown; ocelli yellow. Forewings conspicuously fumate, more clouded in the apical half, with veins brown; entirely dark brown in the overwintered form Apical spines of posterior tibia and proximal segment of posterior tarsi and apical rim of forceps of male genitalia black. Legs, abdomen and genital seg ments black in the overwintered form.

Head almost as wide as thorax, vertical, not deflexed; vertex half as long as wide or longer, gently curved posteriorly, with discal depressions shallow, raised anteriorly near frons, scarcely pubescent anteriorly, slightly below plane of pronotum, rugose; genal cones very short, half as long as vertex, vertical, subacute and more or less truncate obliquely at apex, slightly divergent, pubescent, much below plane of vertex; occiput and frons not visible; antennae short and stout, 1.2 times as long as width of head, with one long, slender and one short. stout setae at apex, with segment III comparatively short, with segment I wider than long and segment II longer than wide, relative lengths of the antennal segment as $2: 3: 4: 3: 3: 3: 4: 4: 2: 3$.

Thorax robust, strongly arched, less rugose than vertex, without pubescence: pronotum distinctly vertical, nearly half as long as vertex, strongly convex; scutum half as long as wide, flat dorsally, with anterior margin rather straight; 
scutellum small, shorter than wide, about $5 \times 7$, typical in shape, continuous to scutum. Legs short, rather slender; posterior tibia with a small but prominent
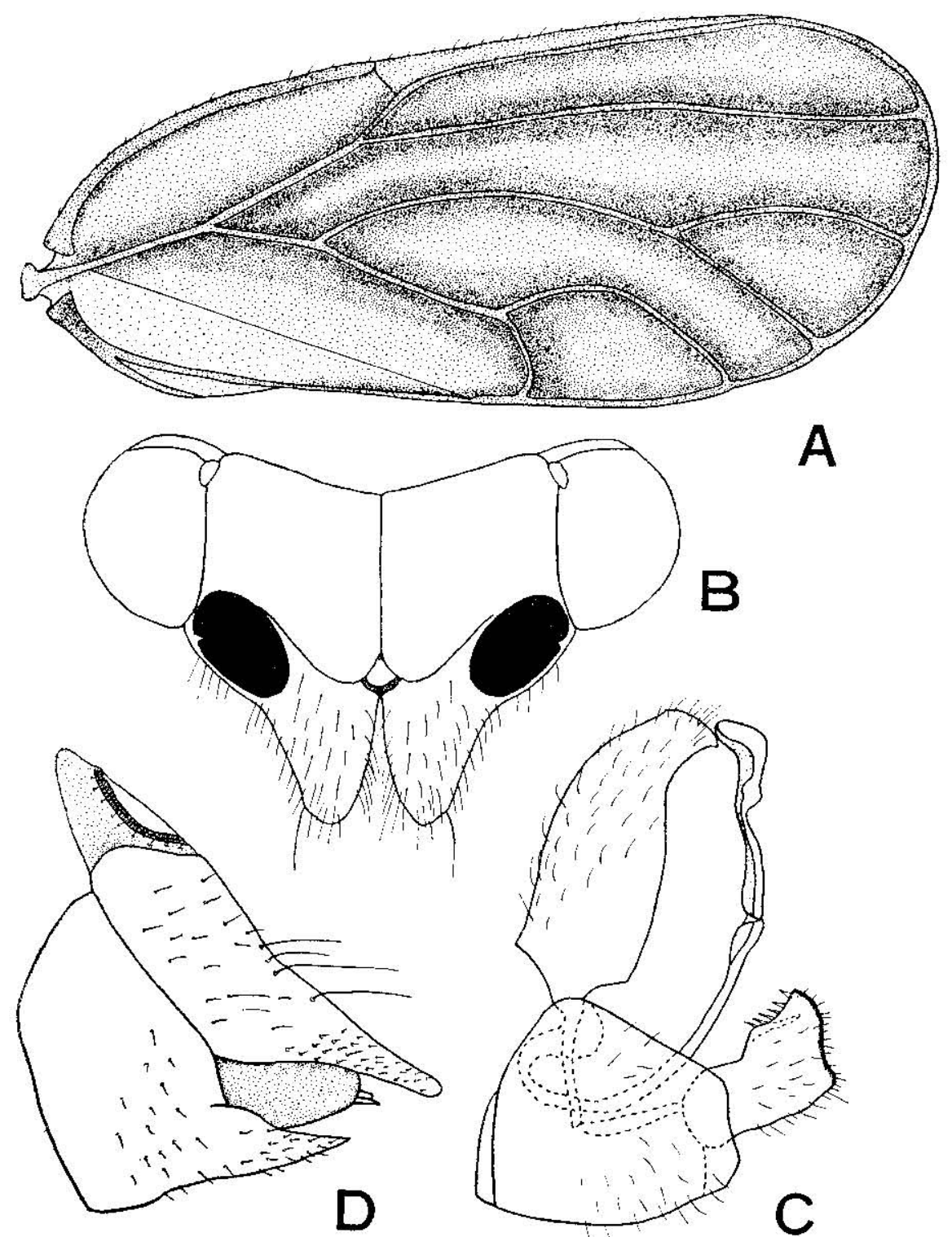

A

Fig. 8. Psylla malivorella [Sasaki].

A. Forewing, 5 B. Head (antennae excluded), frontal aspect, $s$.

C. Male genitalia, lateral aspect. D. Female genitalia, lateral aspect. 
basal spur and with 1 outer and 4 inner apical spines; proximal segment of posterior tarsi with a pair of apical spines; meracanthus in lateral view long and sharp, somewhat horny, pointed at apex, projected ventro-caudad. Forewings long and very elongate, almost 2.5 times as long as wide, with apex rounded, with anterior margin rather straight and pubescent to tip of pterostigma; ptero. stigma large and long, broad and closed basally; Rs more or less sinuate, subparallel with anterior margin, almost reaching apex of forewing, slightly upcurved at apex; M-stem slightly arched; $\mathrm{Cu}_{2}$ rather perpendicular; relative lengths of the veins $\mathrm{M}+\mathrm{Cu}, \mathrm{Cu}, \mathrm{Cu}_{2}, \mathrm{M}, \mathrm{M}_{1+2}$ and $\mathrm{M}_{3+4}$ as $9: 20: 7: 35: 22: 18$; cubital (first marginal) cell rather high, nearly half as high as wide. Abdomen (excl. genital segments) short, less than half as long as width of forewing, bare dorsally and pubescent ventrally.

Male genital segments large, pubescent; proctiger in lateral aspect very long, almost twice as long as forceps, strongly curved caudad apicaliy, broad basally, narrow apically, with anus opened rather caudad; forceps very prominent, in lateral view slender basally and enlarged in the apical half, produced cephalad as figured and bluntly pointed, with apical margin rather oblique and notched near midpoint, with anterior margin turned over as a secondary lobe in the apical two-thirds as figured, with a narrow, sclerotic apical rim at apex, in caudal view strongly curved, slender basally and enlarged apically, in dorsal view touched anteriorly and notched, with inner face beset with small, tuberculate setae over the apical half; aedeagus broadened at base, transformed as -shaped, with first segment almost twice as long as second; subgenital plate in lateral view 0.6 times as high as proctiger, somewhat five-cornered, with dorsal margin rather straight, with apical portion separated with suture making a narrow sclerite cephalad. Female genital segments in lateral view as long as the rest of abdomen or longer, pubescent, sharp; dorsal valve much longer than ventral, with dorsal margin sinuate, attenuate apically, biunt and not upturned at apex; anus small, in larger diameter half as long as the rest of dorsal margin of dorsal valve; inner valve longer than ventral and shorter than dorsal; ventral valve large, very wide at base and strongly compressed midway, acute and not upturned apically.

Length of body $1.4 \mathrm{~mm}$, $1.6-1.8 \mathrm{~mm}$ (to tip of folded wings $2.1-2.3 \mathrm{~mm}$ ? $2.3-2.5 \mathrm{~mm}$ ); length of antenna $0.7-0.8 \mathrm{~mm}, 0.7-0.8 \mathrm{~mm}$.

Distribution: Japan (Honshu).

Specimens examined: 3 और 50 (23) 29 on slides), Mt. Nyuhgasa, Nagano Pref., Honshu, 30 vii. 1962, S. Miyamoto leg. 5.355 , Iriyamabe, nr. Matsumoto, Shinano, 7. v. 1961, Y. Hirashima leg. 14, Minamiminowa, Ina, Nagano Pref., 6. v. 1962 , K. Hara leg. $3231 \%$, 9. iv. $1958 ; 103399$, 8. iv. $1959 ; 3 \therefore 9$; 8. vi. 1962; Mt. Amari (1600 m), Yamanashi Pref., T. Saigusa leg. 1 , Kanayama, Masutomi, Yamanashi Pref., 7. vi. 1962, T. Saigusa leg. 1\%, Hachimantai, Akita Pref., 12. vii. 1962, Y. Miyatake leg.

Host plants: "Ringo"-Malus pumila Mill. var. dulcissima Koidz. [Rosaceae]; T. Sasaki, 1915: 301. "Zumi"--*Malus Sicboldii Rehd. [Rosaceae]; adults, con. firmed at Amarizawa, Yamanashi Pref. in April, 1959 by T. Saigusa.

Differs from other species of the genus in having the very prominent forceps of the male genitalia as figured, broad, obliquely truncate and with a narrow sclerotized rim apicaliy and with the inner surface beset with a patch of strong setae. Colroation and venation of the forewings are similar to those of $P$. pruni (Scopoli) of Europe, but differs from it in having the prominent forceps. 
The author name of this species has been recognized as Matsumura for a long time. However, he had not described this species before T. Sasaki described this anonymously in 1915. Therefore, the authorship should be changed and used as written above. In this matter, I am very much indebted to Mr. Toshio Harada, Nagano Agricultural Experiment Station for checking the old records.

\section{Psylla sorbicola Y. Miyatake sp. nov.}

(Fig. 9, A-D)

3: General colour orange to reddish yellow; antennae with two basal segments orange and becoming brownish towards apex, with three apical segments and tips of each segment (III to VII) black; eyes dark brown to black; ocelli

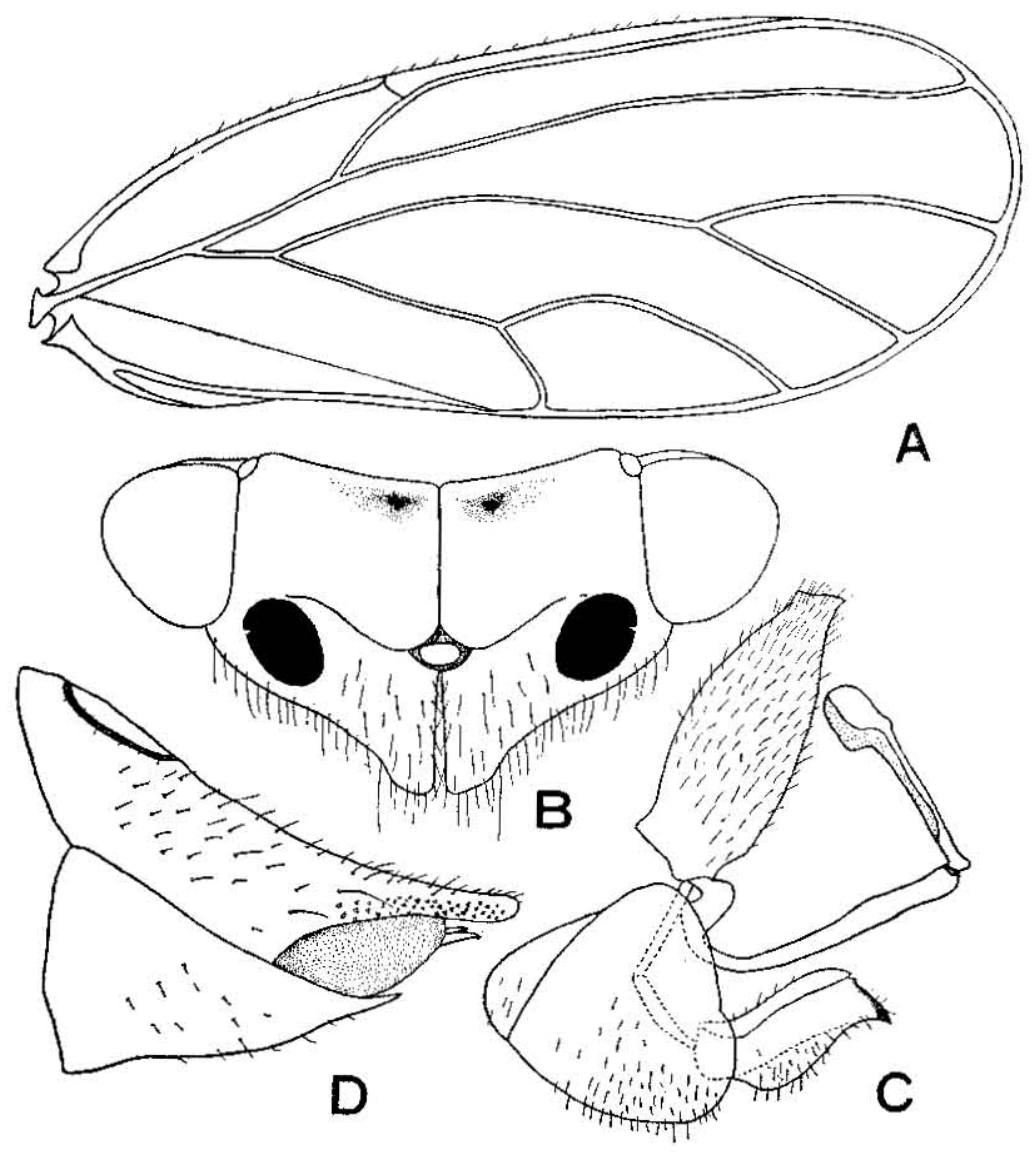

Fig. 9. Psylla sorbicola Y. Miyatake, sp. nov.

A. Forewing, $\hat{6}$. B. Head (antennae excluded), frontal aspect, $\hat{3}$.

C. Male genitalia, lateral aspect. D. Female genitalia, lateral aspect. 
red; pronotum more or less with maculation of dark brownish colour. Forewings flavous or fumate, with veins reddish brown, without spot at tip of clavus. Apical spines of posterior tibia and proximal segment of posterior tarsi and apex of forceps of male genitalia black. Dorsal valve of female genitalia more or less brownish to dark brown apically.

Head rather large, almost as wide as thorax, vertical, slightly below plane of pronotum; vertex shorter than half as long as wide on median line, rugose, with posterior margin gently curved, with discal depressions deep, scarcely pubescent apically; genal cones small, conical, distinctly shorter than vertex, subacute and obliquely truncate apically, slightly divergent, sparsely pubescent; occiput and frons not visible; antennae rather stout and short, 1.3 times as long as width of head, with two apical setae of the different length, III comparatively short, relative lengths of the antennal segments as $3: 3: 5: 4: 4: 4: 4: 4: 2: 3$.

Thorax robust, well arched, not pubescent, less rugose than vertex; pronotum strongly convex anteriorly, distinctly above plane of vertex, slightly over half as long as vertex; scutum rather fiat dorsally; scutellum subtrapezoidal. Legs moderately stout; posterior tibia without distinct basal spur, with 1 outer and 4 inner apical spines; proximal segment of posterior tarsi with a pair of apical spines; meracanthus long, acute at apex, projected ventro-caudad in lateral aspect. Forewings long, very elongate, almost 2.5 times as long as wide, with apex narrow but rounded, with anterior margin pubescent to tip of pterostigma; pterostigma broad and long, 0.6 times as long as Rs, not reaching apex of Rs, basally closed: Rs rather paraliel with anterior margin, slightly sinuate; relative lengths of the veins $\mathrm{Cu}+\mathrm{M}, \mathrm{Cu}, \mathrm{Cu}_{2}, \mathrm{M}, \mathrm{M}_{1+2}$ and $\mathrm{M}_{3+4}$ as $9: 27: 10: 44: 33: 26$; first marginal (cubital) cell as large as second (medial), much wider than high, about $i \times 3$. Abdomen (excl. genital segments) as long as width of head, longer than genital segments, with tergites bare and sternites sparsely pubescent.

Male genital segments moderately large, pubescent; proctiger rather slender, much longer than forceps, curved caudad in the apical half, narrow and truncate horizontally at apex, with posterior margin nearly straight; forceps short, half as long as proctiger, somewhat pear-shaped in lateral view, quite complicated, with anterior margin turned up as a narrow lobe, tapering to acute apex, strongly curved caudad apically, in caudal view very stout, with mesal margins almost parallel to each other, acute and touched at apex, with inner surface beset with a patch of strong, mesal setae in the posterior half; aedeagus moderately long, swollen at base, with first segment stout and 1.3 times as long as second segment, with second segment transformed as semicircular at apex; subgenital plate Iower than proctiger, subtriangular, with dorsal and ventral margins convex outward, with anterior portion separated with longitudinal suture, making a narrow sclerite cephalad. Female genital segments shorter than the rest of abdomen, typical; dorsal valve broad basally and narrow apically, very attenuate and horizontal in the apical half, blunt at apex, much longer than ventral; anus very small, about 0.3 times as long as the rest of dorsal margin of dorsal vaive in larger diameter; inner valve shorter than dorsal but longer than ventral; ventral valve subtriangular in lateral view, with apical portion slender to sharp tip, conspicuously upturned at apex, slightly concave ventrally in proximal half.

Length of body $; 1.6-1.9 \mathrm{~mm}, \quad 1.9-2.2 \mathrm{~mm}$ (to tip of folded wings $22.8-3.0$ $\mathrm{mm}$, $3.1-3.2 \mathrm{~mm}$ ); length of forewing $2.4 .2 .5 \mathrm{~mm}, \quad 2.6-2.7 \mathrm{~mm}$; length of antenna $60.8 \cdot-0.9 \mathrm{~mm}, 0.8-0.9 \mathrm{~mm}$. 
Distribution: Japan (Honshu, Hokkaido).

Holotype (5): Takada-Ohdake (1551 m), Aomori Pref., Honshu, 14. vii. 1962, Y. Miyatake leg. (on Sorbus sambucifolia M. Roemer).

Paratypes: $9 \div 23 \%(2 \div 2 \%$ on slides), the same data as the holotype on the same host. $2 \approx 1$ 을 the same locality as the holotype, 13. vii. 1962, T. Saigusa leg. 299 , Towada Lake, Aomori Pref., Honshu, 13. vii. 1962, Y. Miyatake leg. 1 2\%, Hachimantai, Akita Pref., Honshu, Y. Miyatake leg. 1s, Midagahara, Mt. Tateyama, Toyama Pref., Honshu, 11. x. 1959, I. Hiura leg. 1우 1 우, Tsubakurodake $(2500 \mathrm{~m})$, Nagano Pref., Honshu, 18. viii. 1962, T. Saigusa leg. 1\%, Shiroumadake $(2933 \mathrm{~m})$, Nagano Pref., Honshu, 16. vii. 1962, T. Saigusa leg. 133 \%o, Mts. Daisetsu, Kamikawa-gun, Hokkaido, 18. vii. 1953, K. Sasaki leg. 3001 , Aizankei, Kamikawa-gun, Hokkaido, 19. vii. 1962, Y. Miyatake leg. $1 \lesseqgtr$, Metoh, Ashoro, Tokachi, Hokkaido, 28. vii. 1962, Y. Miyatake leg. 1o, Meakandake, Akan-gun, Hokkaido, 30. vii. 1962, Y. Miyatake leg. 1 \% , Sounkyo, Hokkaido, 17. vii. 1953, K. Sasaki leg.

Ilost plants: "Takane-nanakamado"-Sorbus sambucifolia M. Roemer [Rosa. ceael; adults, confirmed at Takada-Ohdake, Aomori Pref. in 1962 by me. "Nanakamado"-Sorbus commix/a Hedlund [Rosaceae]; aduits, confirmed at Aizankei and Meakandake in Hokkaido in July, 1962 by me.

Differs from hakonensis Kuwayama of Japan in being distinctly smaller, in having the forewings entirely semiopaque, the cubital (first marginal) cell rather triangular instead of quadrilateral, and in having the proctiger pyriform rather than slender. Differs from breviantennata Flor of Europe (Host plant: Sorbus: (Iria $\mathrm{l}$.) in being much smaller, in having the forewings without prominent ma. culations as in breviantemmala Flor and with cubital (first marginal) cell distinctly wider than high, and in having the forceps of the male genitalia broad and ventral valve of the female genitalia not attenuate in the apical half.

\section{Psylla jezoensis Y. Miyatake, sp. nov.}

(Fig. 10, A-D)

$\therefore$ General colour yellow to reddish orange; antennae with two basal segments yellow, with tips of segments IV to VIII brown, with two apical segments black; eyes light to reddish brown; ocelli red. Forewings flavous, with veins yellowish brown. Apical spines of posterior tibia and tarsi, and tip of forceps of male genitalia black.

Head as wide as thorax or slightly wider, subvertical; vertex distinctly longer than half as long as wide on median line, rather flat dorsally, discal depressions very shallow, with posterior margin slightly concave, with anterior margin raised, on same plane of pronotum, not pubescent; genal cones small, broad, defalitely shorter than vertex on median line, slightly longer than wide, rather contiguous, blunt and obliquely truncate at apex, sparsely pubescent, slightly below plane of vertex; eyes rather elongate than hemispherical; antennae short and stout, 1.2 to 1.4 times as long as width of head, with two apical setac of the different length, relative lengths of the antennal segments as $3: 3$ : $5: 4: 3: 3: 5: 4: 2: 3$.

Thorax broad, not strongly arched, not pubescent, rugose as well as vertex; pronotum vertical, half as long as vertex; scutum rather ftat dorsally, half as long as wide. Legs moderately stout, hairy; posterior tibia with a basal spur 
short and tubercular, with 1 outer and 4 inner apical spines ( 3 of them gathered); proximal segment of posterior tarsi with a pair of apical spines; meracanthus projected ventro-caudad in lateral view, acute at apex. Forewings elongate, 2.4 times as long as wide, rounded at apex, with anterior margin pubescent to tip of pterostigma; pterostigma broad and long, but not reaching apex of Rs, basally closed; $\mathrm{Rs}$ subparallel with $\mathrm{Cu}_{2}$ in the apical two-thirds; $\mathrm{M}$ arched; relative lengths of the veins $\mathrm{M}+\mathrm{Cu}, \mathrm{Cu}, \mathrm{Cu}_{2}, \mathrm{M}, \mathrm{M}_{1+2}$ and $\mathrm{M}_{3+4}$ as $8: 19: 11$ : $37: 27: 20$; cubital (first marginal) cell long, nearly as large as medial (second
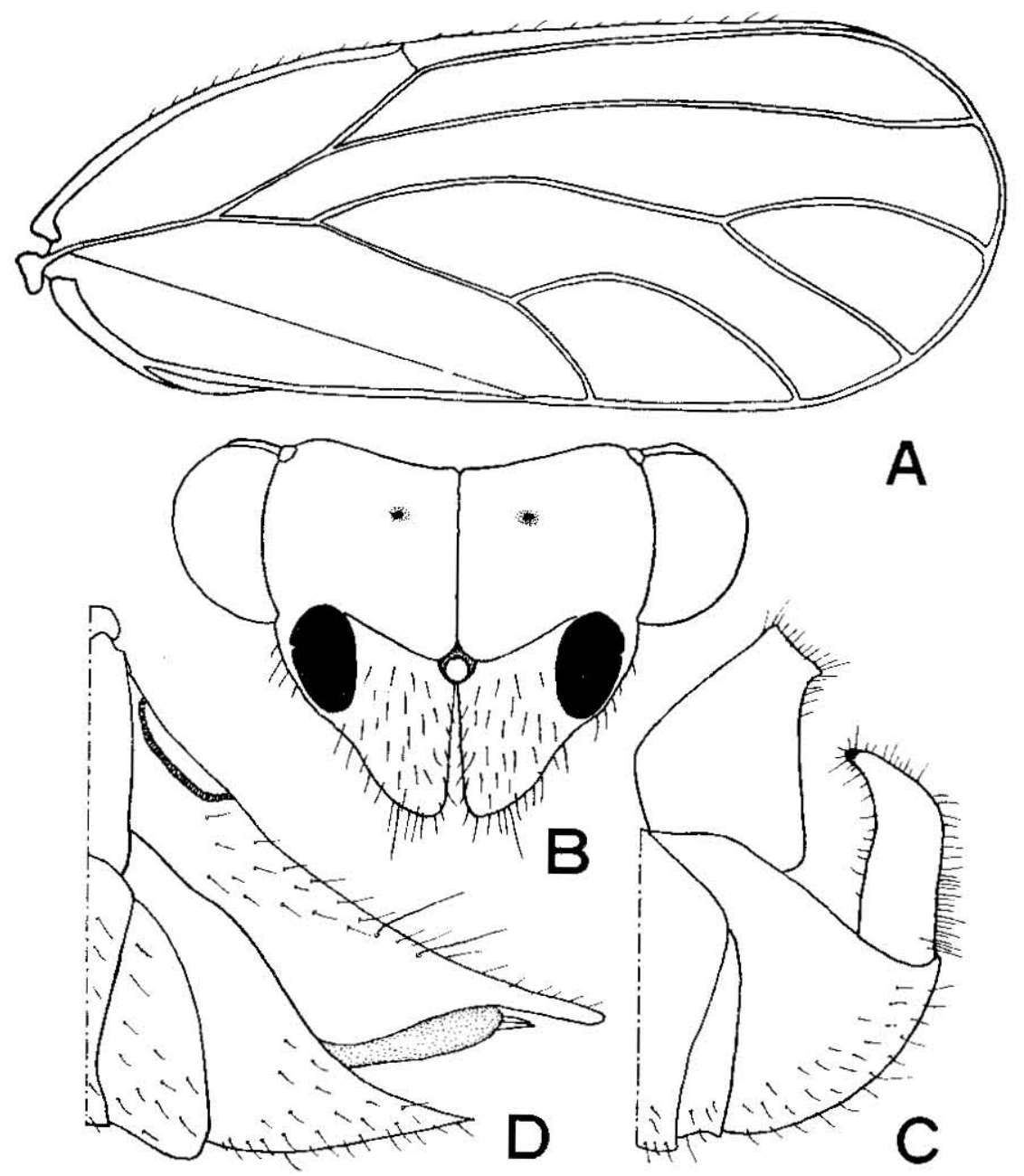

Fig. 10. Psylla jezoensis Y. Miyatake, sp. nov.

A. Forewing, $\hat{0}$ B. Head (antennae excluded), frontal aspect,

C. Male genitalia, lateral aspect. D. Female genitalia, lateral aspect. 
marginal) cell, 1.6 times as wide as high. Abdomen (excl. genital segments) short, half as long as width of head, bare dorsally and sparsely pubescent ventrally.

Male genital segments small, half as long as the rest of abdomen, pubescent; proctiger markedly short, nearly as long as forceps, broad at base and narrow apically, with apical portion slightly curved caudad, with anus open dorso-caudad; forceps in lateral view slender, straight, obliquely narrowed to subacute apex, curved cephalad apically, in caudal view stout at base, gently arched, tapering to acute tips, with inner face beset with long, retrorse setae; subgenital plate comparatively large, higher than proctiger. Female genital segments long and sharp, as long as the rest of abdomen or longer; dorsal valve distinctly longer than ventral, very broad at base, narrowed to subacutely blunt apex, with dorsal margin gently descending and not upturned apically, with ventral margin rather horizontal, with tuft of long setae near midway of dorsal margin; inner valve longer than ventral and shorter than dorsal; ventral valve wide at base and narrowed in the apical third, acute and slightly upturned at apex.

Length of body $\hat{0} 1.4-1.5 \mathrm{~mm}, 1 . \overline{0}-1.8 \mathrm{~mm}$ (to tip of folded wings $52 . \overline{\mathrm{j}}-$ $2.8 \mathrm{~mm}$, $2.7-3.0 \mathrm{~mm}$ ); length of forewing $2.0-2.1 \mathrm{~mm}$, q $2.3 \cdot 2.4 \mathrm{~mm}$; length of antenna $0.8-0.9 \mathrm{~mm}, 0.8-0.9 \mathrm{~mm}$.

Distribulion: Japan (Hokkaido).

Holotype (6): Jozankei, Hokkaido, 15. vii. 1953, K. Sasaki leg.

Paratypes: 2 of $3 q 9$, the same data as the holotype. 1 ; 2 , the same locality as the holotype, 16. vii. 1953, K. Sasaki leg. 1 , Sapporo, Hokkaido, 14. vii. 1953, K. Sasaki leg.

Host plant: unknown.

Differs from ledi Flor of Russia in having the shorter antennae, genal cones broad and contiguous, and in having the proctiger of the male genitalia markedly short, almost as long as the forceps.

\section{Psylla jamatonica Kuwayama}

Psylla jamatonica Kuwayama, 1908, Trans. Sapporo Nat. Hist. Soc. 2: 167.

Distribution: Japan (Hokkaido, Honshu, Shikoku, Kyushu).

Specimens examined: Numerous examples from the following localities:

Nagano Pref.: Ina (vii, Y. Maeta).

Yamaguchi Pref.: Shimonoseki (viii, K. Yasumatsu).

Kagawa Pref.: Zentsuji (i, Y. Miyatake).

Ehime Pref.: Nakadote, Matsuyama (vi, K. Sasaki); Sugitate, nr. Matsuyama (v, K. Sasaki); Omogokei (ix, K. Sasaki); Mt. Ishizuchi (ix, K. Sasaki); Syumura, Syuso-gun (vii, K. Sasaki); Mt. Sara (iv, K. Sasaki); Ishitegawa, Matsuyama (xi, K. Sasaki).

Fukuoka Pref.: Hikosan (iv, K. Yasumatsu, Y. Miyatake; vii, Y. Miyatake; viii, K. Morimoto); Mizunashi (ii, Y. Miyatake); Mt. Sefuri (ii, Y. Miyatake); Kôrasan (iv, S. Miyamoto; vii, I. Hiura); Mt. Wakasugi (ii, Y. Miyatake; viii, S. Miyamoto); Hirao, Fukuoka (v, Y. Miyatake); Hakozaki, Fukuoka (xi, M. Shiga; vii, Y. Miyatake); Mt. Homan (vi, Y. Miyatake); Inunaki (ii, Y. Miyatake).

Nagasaki Pref.: Tae, Goto I. (ix, T. Kawarabata). 
Kumamoto Pref.: Amakusa (vii, Hidaka \& Azim); Kikuchi-suigen (v, Y. Miyatake), Tatsutayama, Kumamoto (i, T. Kawarabata; iii, Y. Miyatake).

Ôita Pref.: Makiguchi (iii, Y. Miyatake); Mt. Kujuh (vii, Y. Miyatake).

Type-series from Sapporo, Tokyo, Moji and Totomi were examined in 1962 (preserved in the Entomological Institute of Hokkaido University).

Host plant: "Nemunoki"...-Albizzia Julibrissin Durazz. [Leguminosae]; adults \& nymphs, confirmed at Hirao, Fukuoka in May, 1958 by me and Hakozaki, Fukuoka in November, 1962 by M. Shiga, and in Ina, Nagano Pref. in July, 1962 by Y. Maeta; eggs, confirmed at Hirao, Fukuoka, in April, 1959 by me.

\section{Psylla elaeagnicola Y. Miyatake, sp. nov.}

(Fig. 11, A--D)

s: General colour reddish brown; two apical segments of antennae, central part of pronotum, maculation of pleurites of thorax, anterior part of postnotum of metathorax, large part of abdomen, dorsal part of femur, apical half of female genitalia and male genitalia except for proctiger black or dark brown. Thorax with a few pairs of stripes on scutum of mesothorax, some brownish laterally and other whitish centrally. Vertex along median line and posterior margin, posterior and lateral margins and anterior angles of scutelium white. Forewings hyaline, with veins light brown, more or less coloured brownish at apex of clavus. Apical spines of posterior tibia and tarsi black.

Head conspicuously wider than thorax, subvertical; vertex as long as wide, raised along median line, with posterior margin sligtly concave, shortly pubescent anteriorly, with discal depressions deep; occiput and frons not visible; genal cones rather slender, as long as vertex or slightly shorter, blunt but more or less obliquely truncate apically, with dense, long pubescence, divergent; antennae short and rather stout, 1.2 times as long as width of head, relative lengths of antennal segments as $2: 2: 9: 5: 5: 5: 4: 4: 2: 3$.

Thorax robust, arched, not pubescent, nearly as long as width of forewings, pronotum nearly vertical, well arched, over half as long as vertex; scutum shorter than wide, about $1 \times 2.2$. Legs short and stout; posterior tibia with a distinct basal spur, with 1 outer and 4 inner apical spines; meracanthus short, projected ventro.caudad, acute at apex. Forewings typical in the genus, narrow basally, with anterior margin hairy almost to tip of pterostigma; pterostigma long and broad, 0.6 times as long as $\mathrm{Rs}$; $\mathrm{C}+\mathrm{Sc}$ thickened; Rs more or less sinuate, not upcurved at apex; cubital (first marginal) cell somewhat quadrate, lower than wide, about $1 \times 1 . \overline{7}$; relative lengths of the veins $\mathrm{Cu}+\mathrm{M}, \mathrm{Cu}, \mathrm{Cu}_{\mathrm{y}}$, $\mathrm{M}_{1+2}$ and $\mathrm{M}_{3++}$ as $1: 2.8: 1: 2.8: 2.7$. Abdomen (excl. genital segments) moderately long, almost as long as width of thorax, sparsely pubescent ventrally.

Male genital segments small, nearly 0.3 times as long as the rest of abdomen; proctiger slightly longer than forceps, broad, gently curved caudad in the apical half; forceps in lateral view rather slender, nearly straight, curved caudad and blunt apically, with posterior margin scarcely convex at midpoint, in caudal view very slender, gently arched to acute apex, touched apically, with inner face beset with retrorse hairs on the basal half; aedeagus short, with basal segment broad and 1.6 times as long as apical segment, with second segment swollen at base and transformed as figured; subgenital plate lower than proctiger, 
somewhat triangular, with apical portion separated with longitudinal suture making narrow sclerite cephalad. Female genital segments almost as Iong as the rest of abdomen, sharp, pubescent; dorsal valve much longer than ventral, narrow, sharp and granulated on the surface in apical portion, acute and strongly upcurved at apex; anus small, in larger diameter 0.4 times as long as the rest of dorsal valve; inner valve shorter than dorsal and longer than ventral; ventral

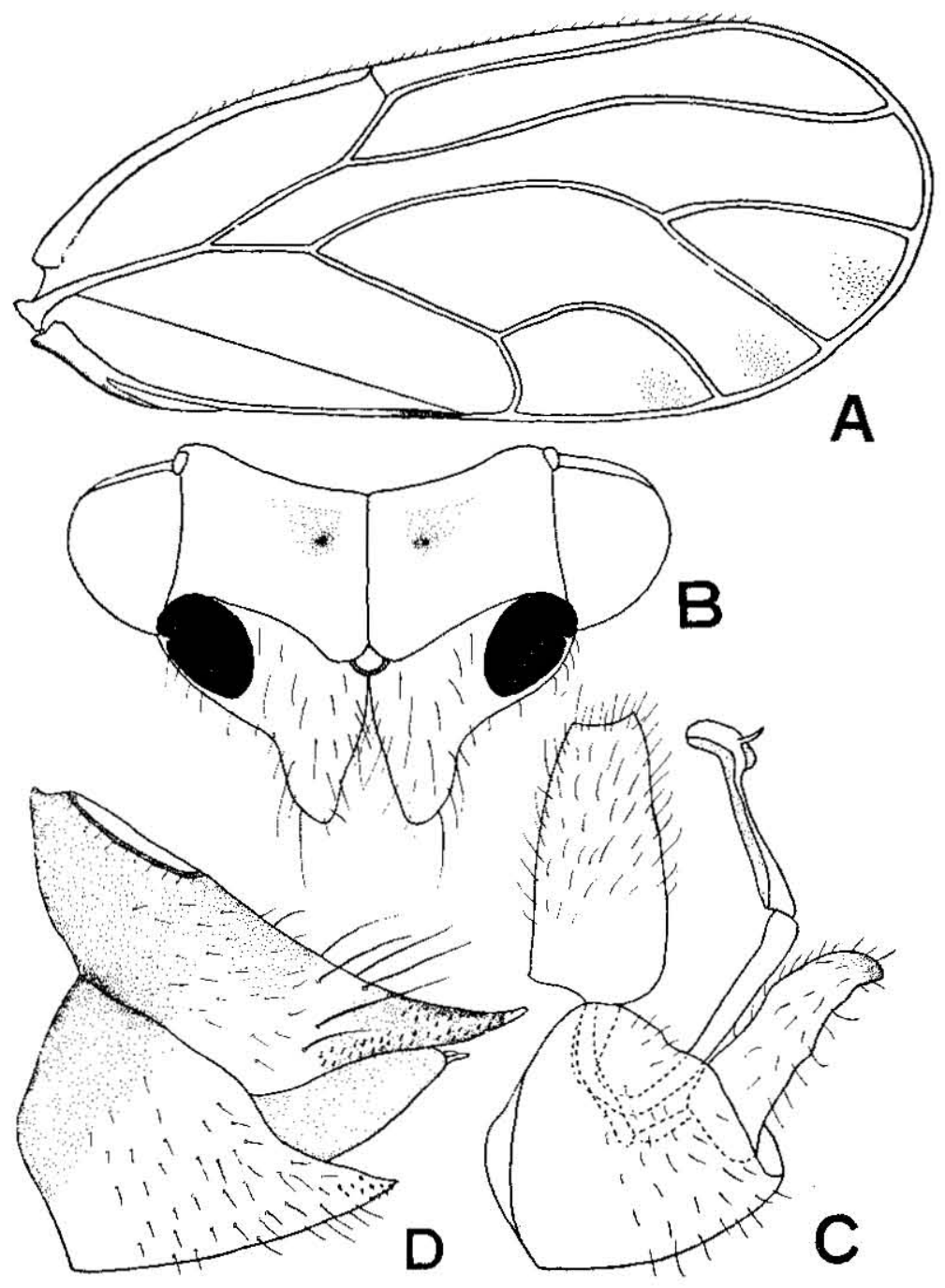

Fig. 11. Psylla clacagnicola Y. Miyatake, sp. nov.

A. Forewing, $\delta$. B. Head (antennae excluded), frontal aspect, ऽ.

C. Male genitalia, lateral aspect. D. Female genitalia, lateral aspect. 
valve somewhat quadrilateral, with apical portion narrow, acute and slightly upturned apically.

Length of body $\& 1.3-1.5 \mathrm{~mm}$, $1.6-1.9 \mathrm{~mm}$ (to tip of folded wings $02.2-2.4$ $\mathrm{mm}$, o 2.4-2.6 mm); length of forewing is $1.8-2.0 \mathrm{~nm}$, $92.1-2.2 \mathrm{~mm}$; length of antenna $0.7-0.8 \mathrm{~mm}$, o $0.7 \cdot 0.8 \mathrm{~mm}$.

Distribution: Japan (Kyushu, Shikoku, Honshu).

Holotype (ô): Mt. Kujuh, Ôita Pref., Kyushu, 18. vii. 1958, Y. Miyatake leg. (on Elaeagnus umbellata Thunb.).

Paratypes: $163519 \%$, the same data as the holotype on the same host. 330 $2 \%$ (on slides), the same locality as the holotype on the same host, 9. iv. 1959, Y. Miyatake leg. 11 $39 \%$, Mt. Ishizuchi, Ehime Pref., Shikoku, 5. ix. 1953, K. Sasaki leg. 2ø, Takada-Ohdake, Aomori Pref., Honshu, 13. vii. 1962, T. Saigusa leg.

Host plant: "Akigumi"-Elaeagnus umbellata Thunb. [Elaeagnaceae]; nymphs \& adults, confirmed at Mt. Kujuh, Ôta Pref. in April, 1959 by me.

Differs from kitshuensis Kuwayama in being much smaller, in having the genal cones shorter and slenderer, the forceps of the male genitalia much slenderer, short and less curved caudad, and the dorsal valve of the female genitalia much shorter and less upturned. Differs from elacagni Kuwayama and fulguralis Kuwayama in lacking the prominent maculation of the forewings and transparent.

\section{Psylla tenuata Jensen}

Psylla tenuala Jensen, 1951, Hilgardia 20 (16): 315, figs.

Distribution: *Japan (Honshu), California.

Specimens examined: 1 i 697 , Uchinokaya, Ina. 28. v. 1962, K. Morimoto leg.

Host plants: Salix laevigata [Salicaceae]; nymphs \& adults, Jensen, 1961 : 31j-316 (in California). Salix sp. [Salicaceae]; adults, confirmed at Uchinokaya, Ina in May, 1962 by K. Morimoto.

\section{Psylla melanoneura Förster}

Psylla melanoneura Förster, 1848, Verh. naturw. Ver. preuss. Rheinlande $3: 75$. Psylla crataegi Förster, 1848 (nec Shrank, 1801), ibid. 3 : 75.

Psylla pityophila Flor, 1861, Kat. d. Rhynch.: 369.

Psylla oxycanlha Meyer-Dür, 1871, Mitt. Schw. Ent. Ges. 3 : 393, 398.

Psylla similis Meyer-Dür, 1871, ibid. 3: 393, 398.

Distribution: *Japan (Hakkaido, Honshu, Shikoku, Kyushu), Europe.

Specimens examined: 1 , Sapporo, 14. vii. 1953; 1 , Jozankei, 16. vii. 1953; Hokkaido, K. Sasaki leg. 1\%, Aizankei, 17. vii. 1962, Y. Miyatake leg.; 1 q, Mt. Daisetsu, 22-24. vii. 1959, T. Kawarabata leg.; 23 ; Kurodake, Mts. Daisetsu, 21. vii. 1962, Y. Miyatake leg.; Kamikawa-gun, Hokkaido. 695779 , 13. vii. 1962, T. Saigusa leg.; $2 \$ 52 \%$, 14. vii. 1962, Y. Miyatake leg.; Takada-Ohdake, Aomori

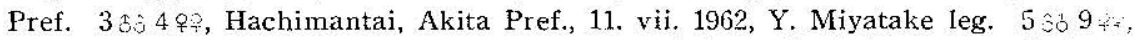
Kitazawa, 7-14. vii. $1959 ; 3005 \%$, Senjyodake-Shirane-kitadake, 28-29. vii. 1959 ; Yamanashi Pref., Y. Miyatake leg. 2 is 1\%, Karuizawa, 7-14. vii. 1959, K. Morimoto leg.; $4 \%$, Tsubakuro-dake $(2500 \mathrm{~m})$, 18. viii. 1962, T. Saigusa leg.; Nagano Pref. 5353 q̧̣, Mt. Ishizuchi, Iyo, 5. ix. 1953, K. Sasaki leg. Is 1 , Mt. Kujuh, 
Ôita Pref., 18. vii. 1958, Y. Miyatake leg. (The Japanese specimens were com pared with the European ones with Dr. Eastop's favour of the British Museum.)

Host plant: Cratacgus oxycantha L. [Rosaceae]; Aulmann, 1913: 20 (in Europe).

\section{Psylla satsumensis Kuwayama}

Psylla satsumensis Kuwayama, 1908, Trans. Sapporo Nat. Hist. Soc. 2: 177 (Kagoshima).

Distribution: Japan (Shikoku, Kyushu, *Ryukyu).

Specimens examined: 11 to 12+\%, Okinoshima, Fukuoka Pref., 20. v. 1933, Esaki \& Hori leg. 2₹̊, Iwayasan, Nagasaki Pref., 3. viii. 1957, H. Kamiya leg. 29 ̇ิ $35 \%$, Tomioka, Amakusa, 13. v. 1960, K. Morimoto leg. 1, 29. v. 1953, I. Hiura leg.; 3 ذิ $\mathbf{5}$ 우, 29. iv. 1962, F. Nakasuji leg.; Cape Sata, Kagoshima Pref. 1 o, Kashima, nr. Matsuyama, 3. vi. 1954, K. Sasaki leg. $2 \varsigma 51$ ?, Hirara, Miyako I., 16. iii. 1962, Y. Arita leg. 1\%, Yarabu, Ishigaki I., 27. iii. 1962, S. Tamai leg.

Type-series from Kagoshima were examined (preserved in the Entomological Institute of Hokkaido University).

Host plant: "Sharinbai"-*Rhaphiolcpis umbellala Makino var. Mertensil [Rosaceae]; nymphs \& adults, confirmed at Tomioka, Amakusa in May, 1960 by K. Morimoto.

\section{Psylla aisanensis Y. Miyatake, sp. nov.}

(Fig. 12, A-C)

3: Very closely similar to the preceding species, Psylla sorbicola sp. nov. in general characters and colorations, but distinguishable from it in the following characters :

1. Genal cones larger than that of sorbicola, as long as vertex or longer more divergent as figured, blunt at apex.

2. Forewings flavous rather than fumate as in sorbicola.

3. Rs more sinuate, slightly upturned at apex.

4. $\mathrm{Cu}_{1}$ more strongly arched, subparallel with $\mathrm{Cu}_{\text {\% }}$.

5. Cubital (first marginal) cell somewhat quadrilateral, rather high, $1 . \overline{3}$ times as wide as high (2 times in sorbicola).

6. Posterior tibia with basal spur which is short but prominent.

7. Forceps of male genitalia in lateral view much more slender, produced neither cephalad nor caudad, without any secondary lobe, tapering to blunt apex which is slightly curved caudad, in caudal view nearly straight to acute and touched apices, with inner face without any short, strong. tuberculate setae but hairs.

c: unknown.

Length of body $; 1.7-1.8 \mathrm{~mm}$ (to tip of folded wings $32.9-3.1 \mathrm{~mm}$ ); length of forewing of $2.4-2.5 \mathrm{~mm}$; length of antenna $80.8-0.9 \mathrm{~mm}$.

Distribution: Japan (Hokkaido).

Holotype (b): Aizankei (Aisan), Kamikawa-gun, Hokkaido, 18. vii. 1962, Y Miyatake leg. (on Sorbus commixla Hedlund). 
Paratypes: $1 \delta$, the same data as the holotype on the same host, Y. Miyatake leg. $4 \delta \tilde{\delta}$, the same locality as the holotype on the same host, 19. vii. 1962, Y. Miyatake leg.

Host plant: "Nanakamado"-Sorbus commixta Hedlund [Rosaceae]; adults, confirmed at Aizankei in Hokkaido in July, 1962 by me.

Differs from ledi Flor in having the antennae distinctly shorter than 1.5 times as long as the width of head (much more than 1.5 times in ledi Flor) and spotted black at the tips of each segment from III to VIII besides two apical segments black.

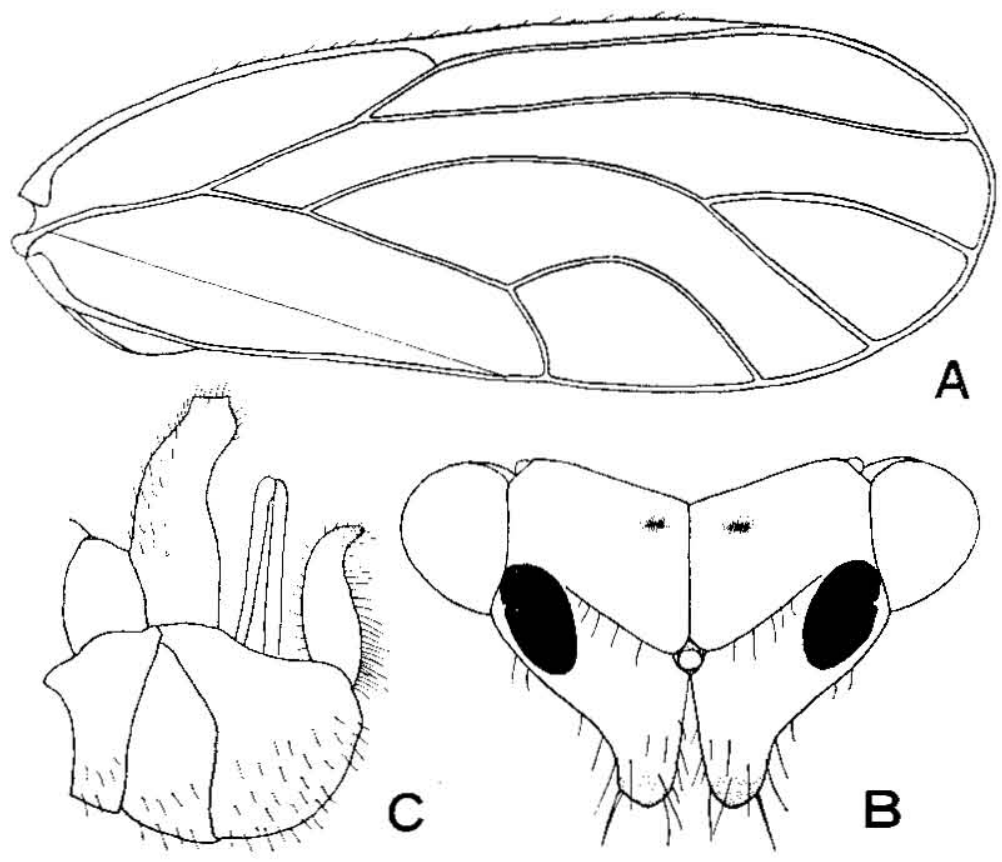

Fig. 12. Psylla aisanensis Y. Miyatake, sp. nov.

A. Forewing, $\hat{\imath}$ B. Head (antennae excluded), frontal aspect,

C. Male genitalia, lateral aspect.

\section{Psylla kuwayamai Crawford}

Psylla tripunctala Kuwayama, 1908, (nec Fitch, 1851), Trans. Sapporo Nat. Hist. Soc. 2: 174. (nom. praeocc.)

Psylla kuwayamai Crawford, 1911, Pomona Coll. J. Ent. 3: 432.

Distribution: *Japan (Shikoku, Kyushu), Formosa.

Specimens examined: 11 ¿ภ 20\%9, Hikosan, Fukuoka Pref., 10-12. v. 1958, Y.

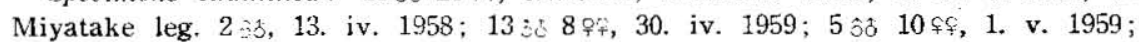


Hirao, Fukuoka, Y. Miyatake leg. 1;, Hakozaki, Fukuoka, 1. v. 1959, Y. Miyatake leg. 2 $\mathrm{d}$, Kôrasan, nr. Kurume, 22. iv. 1955, S. Miyamoto leg. 2 ㅊํ 3 of, Mt. Kosho, Fukuoka Pref., 21. v. 1959, S. Miyamoto leg. 8 \& 11 \%:, Mt. Fukuchi, nr. Kokura, 5. v. 1962, Y. Miyatake leg. 1\%, Ukidake, Saga Pref., 30. v. 1958, T. Hidaka leg. 3 우, Kikuchi-suigen, Kumamoto Pref., 28. v. 1962, Y. Miyatake leg.

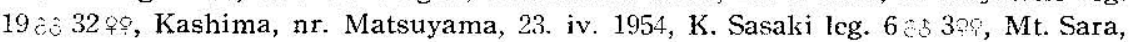
Iyo, 11. v. 1954, K. Sasaki leg.

Type-series cxamined: $2502 \%$ from Arisan, Formosa in the Entomological Institute of Hokkaido University.

Host plant: "Shirodamo"-*Litsea glauca Sieb. [Lauraceae]; adults \& nymphs, confirmed at Hikosan, Fukuoka Pref. in May, 1958 and Hirao, Fukuoka in April, 1959 by me; adults, nymphs \& eggs, confirmed at Hirao, Fukuoka in May, 1959 and Kikuchi-suigen, Kumamoto Pref. in May, 1962 by me.

The Japanese examples of this species lack the distinct maculae or spots of brownish colour on the membrane in addition to ones on the veins. 